

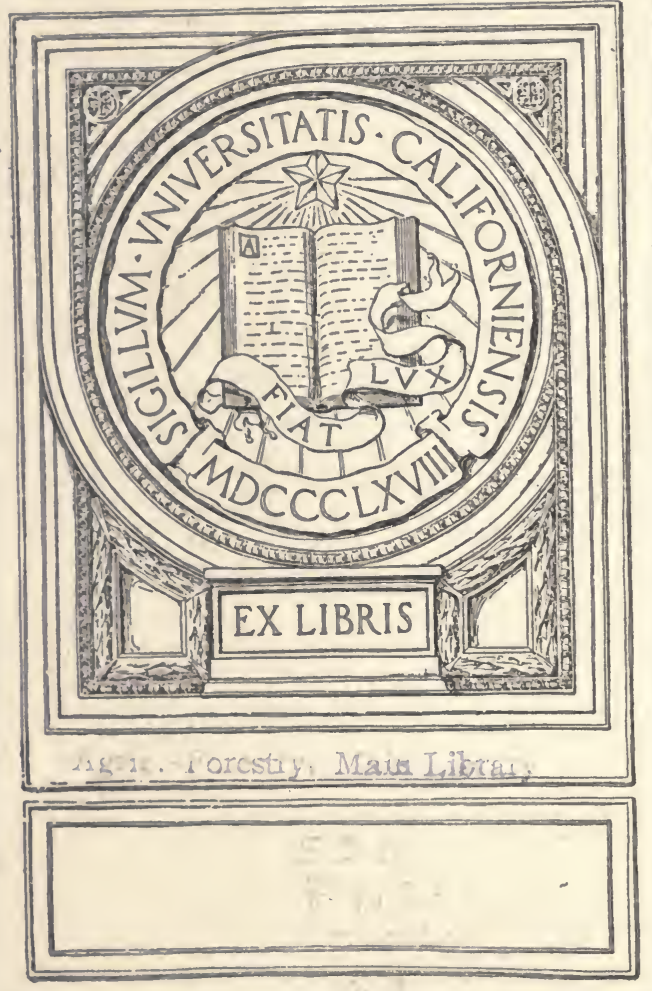


1. 




\section{THE FORESTS OF}

PLYMOUTH COUNTY

MASSACHUSETTS STATE FORESTER

1918

\section{BOSTON}

WRIGHT \& POTTER PRINTING CO., STATE PRINTERS

32 DERNE STREET 




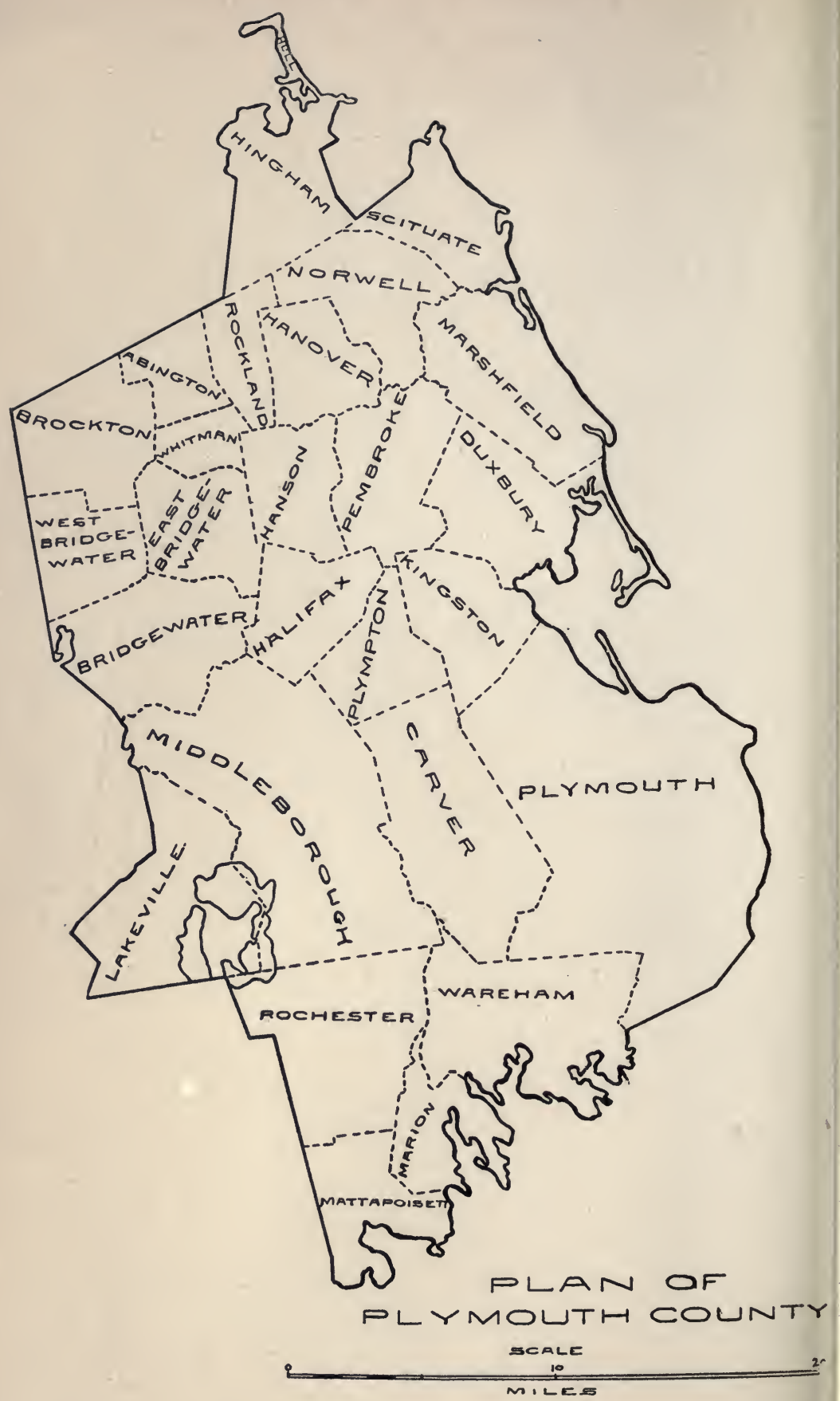


- THE FORESTS

\section{OF PLYMOUTH GOUNTY}

\section{The Results of a Forest Survey}

OF THE

\section{Twenty-seven Towns in the County}

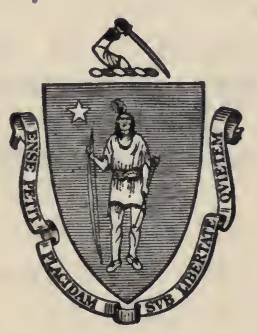

\section{BY JAMES J. MORRIS}

Under the direction of F. W. RANE, State Forester

MASSACHUSETTS STATE FORESTER, 1918

BOSTON

WRIGHT \& POTTER PRINTING CO., STATE PRINTERS

32 DERNE STREET 
Publication of this Document APPROVED BY THE

Supervisor of Administration. 


\section{FOREWORD.}

We are presenting herewith the results of the forest survey of Plymouth County, the second county to be so studied. The field work of collecting the data here included was carried out under the general direction of Mr. P. D. Kneeland, M.F., assistant forester in charge of utilization, while the crew in the field was in charge of Mr. H. E. Henshaw. The work of compilation and of arranging the data in the form of a bulletin was undertaken by Mr. James J. Morris.

The facts developed in these county surveys are now tabulated for the first time, and cannot be arrived at in any other manner. It is believed that they will prove valuable to those interested in our present and future forestry development.

F. W. RANE,

State Forester. 


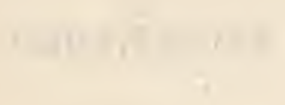

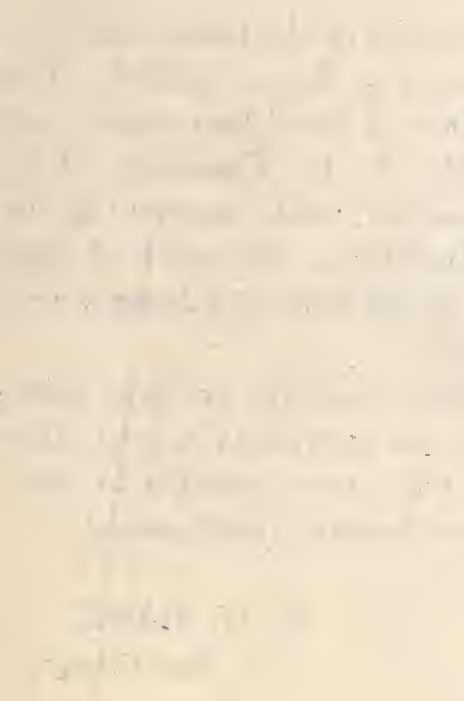

- 
<smiles>[CH]1CC1</smiles> 


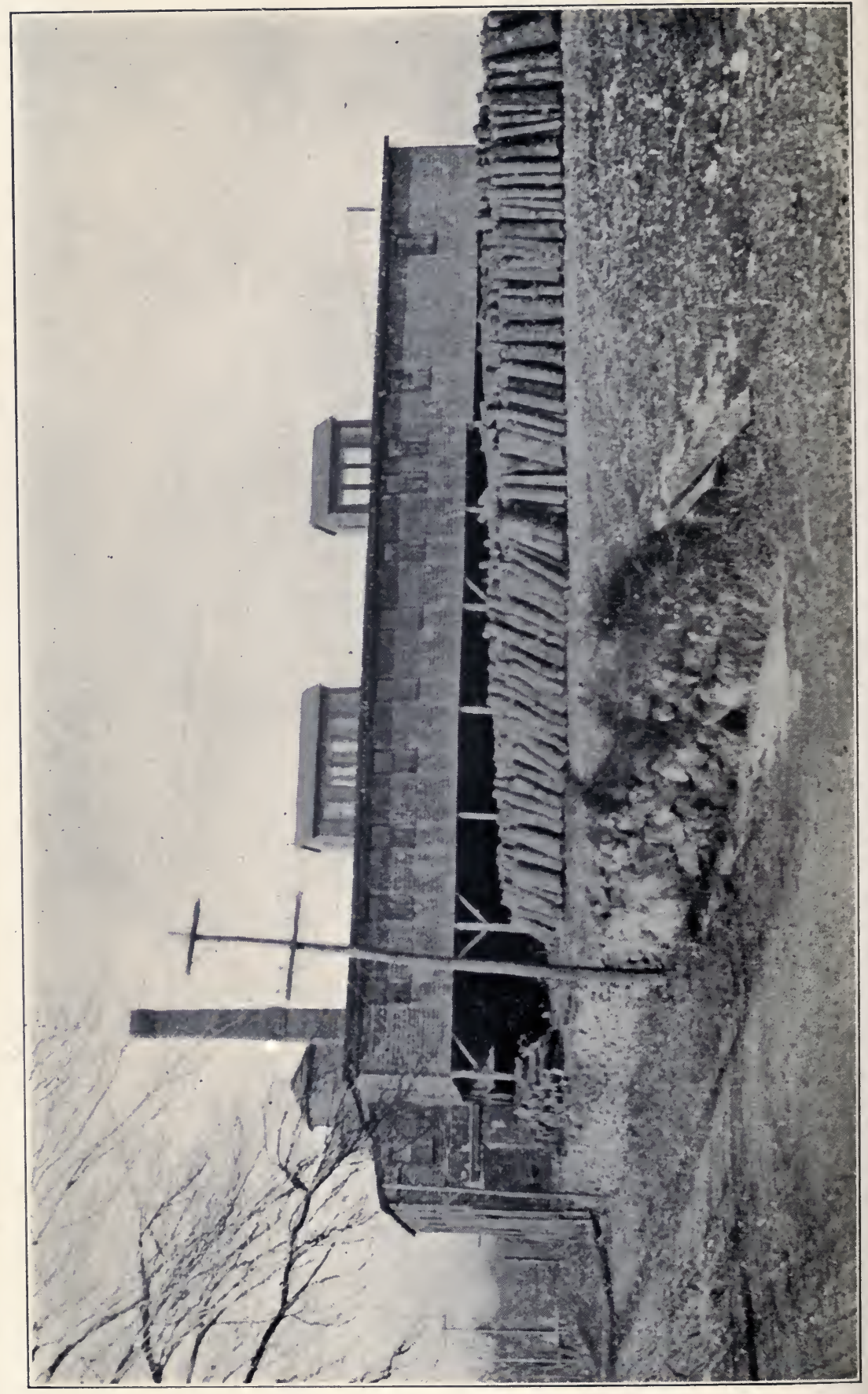




\section{THE FORESTS OF PLYMOUTH COUNTY.}

\section{Explanation of Survey.}

The survey of the several towns of Plymouth County is the second work of this kind attempted by the State forestry department. The other survey, that of Worcester County, was carried on at odd times, and extended over a period of three years. The data were collected and published last winter in the form of a bulletin, which was entitled "The Forests of Worcester County.",

In the Worcester County bulletin the reasons for making forest surveys of the different counties of Massachusetts were explained in detail, but it will not be amiss here to review briefly some of the main reasons.

Every manufacturing concern or business of any kind at some time or other takes an inventory of its stock. Without such an inventory no business can be carried on to the best advantage. The stock, or raw material, of forestry work is forest land, and since the State forestry department of Massachusetts is just what its name implies, the raw material with which this department must deal is the forest lands of Massachusetts.

If the woodlands of Massachusetts were made up of but one or two species of trees, or if the various species of trees were all of the same height or diameter size, this inventory would be a comparatively simple matter. But such conditions do not exist. Scattered throughout the State are many different kinds of trees differing greatly in importance, value, life habits, etc., from each other. Moreover, since the woodlands have been repeatedly cut over at different times for many years, we find existing a variegated collection of trees of all sizes and conditions; in fact, nearly every woodlot differs to a greater or less extent from others. 


\section{Method of SURvey.}

In Worcester County each town was covered by one man, who did all the field work. In Plymouth County the men worked in a crew, each man covering a certain assigned section of the town which was being mapped. When one town was finished the men moved on to the next. There were several distinct advantages in this arrangement. Since the men camped in tents it was possible for them to choose a central location for their camp site and thus save time, inasmuch as in going to and from their work they were not obliged to cover the same ground as they would have been had they stopped at a farmhouse or hotel in one corner of the town, as was often the case in Worcester County. The cost of the survey was also lighter, the only expense incurred being for foodstuffs, since the men and camp equipment were moved from place to place by one of the department trucks.

For the main part, however, the methods followed in making this survey were similar to those followed in Worcester County. The men worked by compass and pace, using a copy of the United States topographical map as a guide map for each town. Each man would start at some convenient point on a road or edge of a pond and run a straight line through to the town line and then back to the opposite town line on a course parallel to the first, but one-half mile distant. Care was taken when laying off these parallel lines to have them cut the roads so far as possible; that is, if the majority of the roads in a certain town ran in an easterly and westerly direction the strips were run in a northerly and southerly direction, or vice versa. Cutting the roads in this manner enabled the men to get a truer idea of the actual forest conditions, and it was possible to obtain a more accurate average, because if the strips were run in the general direction of the roads some of them would parallel the roads, and since in most cases the type found along the roadsides, which is largely tillage, is not typical of the land lying a few hundred feet farther in, the data obtained in this way would not be trustworthy, as the lines would show an amount of farm and tillage land out of proportion to actual conditions. 
For convenience and brevity in the field, symbols representing the various types, diameter classes, moth infestations, etc., were used. These symbols are somewhat similar to those used in the previous survey. The map work of each town has been completed, and photographic enlargements of the topographical maps used as a base are to be found at the office of the State Forester. These maps show the strip lines which were run in each town, and contain a symbolic explanation of the different types, size classes, etc. Tables containing summaries computed from the information obtained from the field work are.contained in this bulletin.

The following diagram may serve to illustrate the method used in making this survey:

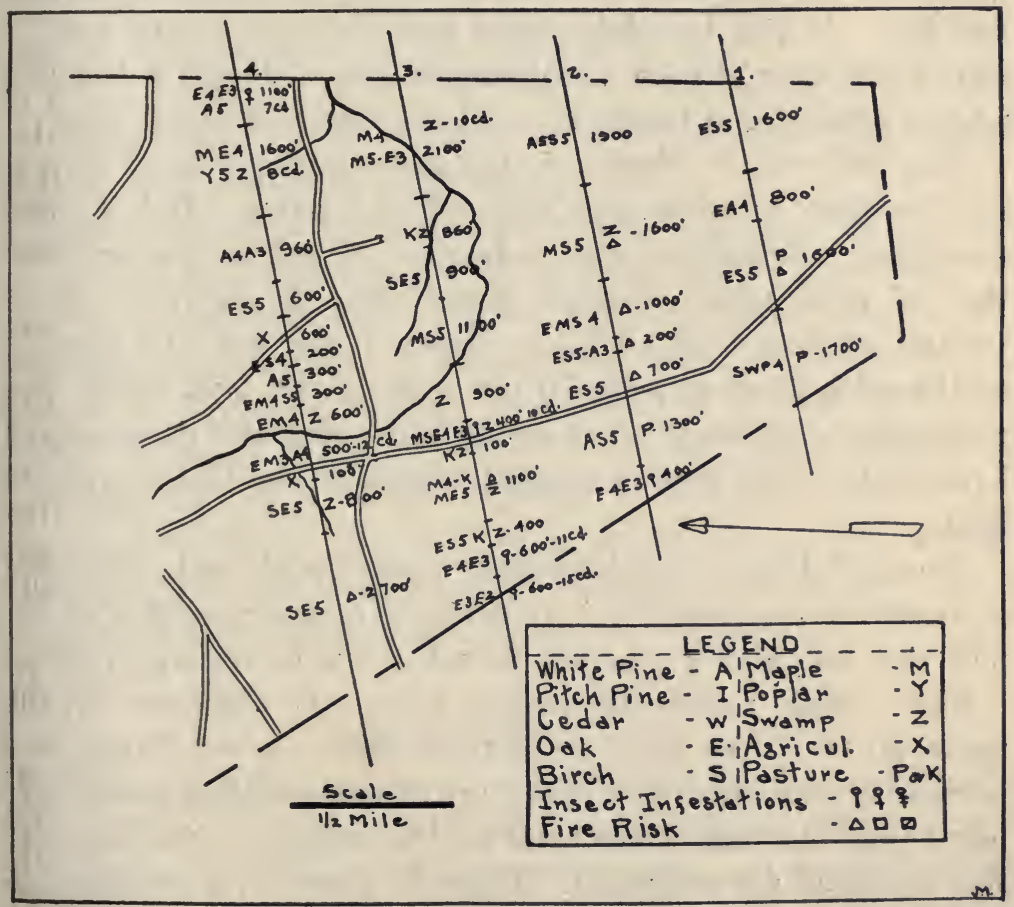

Map of northern section of Rockland, showing method of survey.

Lines 1, 2, 3 and 4, running approximately east and west, represent strip lines one-half mile apart. On Line 1, and near the top of the plate, are the symbols "E S 5, 1600'." Consult-. ing the legend we learn that along this line for a distance of 
1,600 feet were found oak and birch of sprout size in mixture, the number 5 representing the size class. Oak predominates, since the letter "E," representing oak, precedes the letter "S," representing birch.

\section{Forest Types.}

On account of the difference in topographical and climatic conditions, the types of Plymouth County vary to a considerable extent from those of Worcester County. Following is a list of types used and a brief explanation of each:-

White Pine. - This type consists of white pine in pure stands, that is, in stands made up of 80 per cent. or more of the one species. There is still a considerable amount of this type found throughout the county in spite of repeated cuttings and fires. It may be safely stated that there are several million feet of this type of good merchantable size, although it is somewhat scattered and found as a rule in stands of small areas.

Pine and Oak. - Stands of this kind are made up of 70 per cent. or more of white pine and oak in mixture. It is a common type. Sometimes the proportion of oak is greater than that of pine, while at other times there is about an equal amount of each. In all cases, however, the oak and pine in combination form at least 70 per cent. of the total stand, the remainder being made up of maple, pitch pine and unimportant hardwoods. This type is generally found on the higher gravelly lands.

Pine and Maple. - Substituting maple for the oak, this type is similar to the preceding. It is not so common as that of the pine and oak, and is generally found in low or swampy lands.

Oak. - This forms the largest type. It embraces stands made up of 80 per cent. or more of oak. A very large proportion in size class 5 is made up of the so-called scrub oak. More than one-half of the total for the county is of a diameter size too small for cordwood. There is, however, a considerable amount large enough for saw-logs.

Maple (Swamp Type). - Consists of nearly pure stands of maple. This type is found on low, wet land, and is fairly common. A good proportion is made up of species of cordwood size, with a moderate representation of the larger size classes.

Pitch Pine Type. - Next to the oak this is the largest indi- 
vidual type found. It is found in all size classes, but more than 50 per cent. consists of the No. 5 , or smallest, class. It is often found in pure stands, but generally contains some other tree in mixture. Scrub oak is its most common associate.

\section{Size Classes.}

In the Worcester County survey but four size classes were used. As an experiment it was decided in the Plymouth survey to split the No. 4 size in two, thus forming five size classes, and differentiating the small brush from saplings. Except for forestry purposes, such as determining more exactly the type of land on which planting might be done without preliminary brushing, the result does not warrant the distinction., Following is an explanation of the various classes:-

No. 1 forms the largest size class, and contains species whose diameters breast high average 10 inches or better, and whose height will average 60 to 80 feet.

No. 2 represents trees whose average diameters run from 8 to 10 inches, and whose height will average about 50 to 70 feet.

No. 3 constitutes the cordwood size, and species of this class average about 5 inches in diameter and 40 to 50 feet in height.

No. 4 embraces saplings and small cordwood, or thrash. Trees falling in this diameter class average about 2 inches in diameter and 30 to 40 feet in height.

No. 5 is formed of very young sprout or stunted growth, such as scrub oak, stunted pitch pine, etc. In no case do the diameters run higher than 2 inches.

\section{NoN-Forest Types.}

Tillage and Hay. - Land covered by this heading is all under cultivation. Included in this type is all the farming and agricultural land, with the exception of pasture and cranberry bogs.

Pasture. - In the Worcester survey much land which could not be classed exactly as No. 5 forest type, owing to the small amount of wood growth on it, and yet which was not actually used as grazing land, was classed as brush pasture.

In this survey the heading "Pasture" includes only such lands as are actually used as such. This accounts to a certain 
extent for the great difference in the pasture totals of Worcester and Plymouth counties.

Water. - All inland waters fall under this classification: ponds, lakes, rivers and brooks. The figures are a little lower than those of the Waterways Commission, but considering the necessarily rough method in which they were obtained the results are very satisfactory.

Residential. - This term explains itself. It also includes business sections, cemeteries, fair grounds, etc.

Cranberry Bog. - Much of the low, mucky lands along streams is suitable for the raising of cranberries, and advantage has been taken of this fact. The area covered by these bogs, although almost negligible as compared to the total area of the county, is, nevertheless, worthy of mention because of the importance of the product.

Marsh. - This term has been used to cover two distinct types. In seacoast towns it applies to salt marsh, while in inland towns it covers the open swamps.

\section{Plymouth County.}

Plymouth County lies in the southeast corner of Massachusetts, just north of Cape Cod. It contains approximately 440,000 acres. Plymouth, a town of about 13,000 population, situated on the coast in the central and eastern part, is the county seat. Brockton is the commercial center, and is important from an industrial standpoint. Other important towns are Middleborough, Whitman, Bridgewater and Rockland. All of these towns contain manufactories of various kinds, principally shoes.

In the western part the Cape Cod branch of the New York, New Haven \& Hartford Railroad runs in a northerly and southerly direction the entire length of the county, while another branch follows the eastern coast line as far south as Plymouth. A line of the same road running east and west connects Plymouth and Middleborough, and in the north a connecting line runs to Plymouth. Electric roads traverse the county in various directions, connecting all the principal cities and towns. On the whole, it may be said that the railroad facilities in the county are good, except in the southern part. 
The products of the county are many and varied. Among the most important may be mentioned shoes, rope, cotton cloth, rubber products, boxes, crates, shooks and shoemaking tools.

The important farming products are hay, potatoes, cranberries and miscellaneous vegetables. Dairying is not now a very important industry, and is becoming less so year after year. Stock and poultry raising is practiced to a slight extent.

Along the seashore are many fine summer resorts. Hundreds of fine residences have been built, and these resorts are constantly attracting people in larger numbers to enjoy the ocean scenery for which the shores of eastern and southern Plymouth County are justly famous.

\section{Topography and Soils.}

Running practically the entire eastern length of the county, along the coast, and extending inland roughly about 5 miles, is a strip of rolling, knobby land with basin-like intervales. The hills are mostly rounded, irregular of distribution, and in very rare cases rise beyond 100 feet in altitude. This strip is made up of, a terminal moraine, and is more rugged than the other sections of the county.

The remainder, which means practically the whole of the county, is made up of a level to gentle rolling topography. The elevation of the hills ranges from 100 to 200 feet. Numerous ponds abound, among the principal of which may be mentioned Assawompsett, Long Pond and Quittacas, all situated mainly or in part in the town of Lakeville. Several swamps of large areas also occur, the Great Cedar Swamps of Bridgewater and Middleborough being the most important.

The drainage of the county is effected mainly through several small rivers and their tributaries. The Weweantic River drains to the south into Buzzards Bay. The Taunton River, emptying into Mount Hope Bay, drains part of the western and central areas. Weir and Fresh rivers are the principal streams in the north, while North, South and Jones rivers drain to the east. Other important streams are the Mattapoisett, Wankinco, Agawam and Sippican. Many of the ponds and lakes throughout the county have no apparent outlet, and it is possible, par- 
ticularly so in the eastern section, that they empty into the ocean through a subterranean flow which drains to a considerable extent the whole country.

Monk's Hill in Kingston is the highest elevation in the county.

The soils of the northern part of Plymouth County are mostly a light to heavy fine sandy loam, with outcroppings of granite, gneiss and schist. Much of this soil is forested, but that which is cultivated produces good and various crops. The sandier and stony types are found mostly in pastures.

Although the larger part of the soils of the central and southern sections are also sandy loam, they are coarser than those of the northern section, and carry a considerable amount of gravel and fine pebbles. Through Plymouth, Wareham and Middleborough deposits of muck occur. This soil is used extensively for growing cranberries, and, as shown in the tables, quite a sizable area is under cultivation.

\section{Forest Conditions.}

In the reports of the overseers of the earlier Plymouth County settlements reference is often made to the forests, but such references contain very scanty information as to their composition. It is probable, however, that at the time of the landing of the Pilgrims the greater part of the county was forested with large and thrifty virgin stands of white and pitch pine, oak and maple, - pine in uplands, oak and maple in lowlands.

We know that much of the pine was cut and shipped to England to be used for masts for the English navy, and also that England depended to a large extent upon New England pitch pine for her naval stores.

The original forest types exist to-day, but in a much depleted condition. Over large areas fires have swept repeatedly, burning off the humus - the forest floor covering - and greatly impoverishing the soil in many sections. From these fire-swept areas the original white or pitch pine stands have disappeared, and in their places are growths of scrub pitch pine and oak.

Throughout the greater portion of the county, however, white pine can be grown, and areas now given over to scrub oak should be reforested. On the sandier areas Scotch and good 
grade pitch pine could be grown with success. In fact, reforestation has been carried on successfully in nearly all parts of the county. The State Forest Commission has recently acquired a tract of several thousand acres of land in the town of Carver, and this department is planting large quantities of white and Scotch pine there every year.

As mentioned above, white pine of good grade is still found in fair quantities and in pure stands distributed throughout the county.

It may be well to regard briefly the distribution of the various types. Practically all of the types are universally distributed, and in nearly every case all of the various size classes are found in each town.

The towns of Bridgewater, Hingham and Pembroke contain the highest percentages of white pine, while Abington, Plymouth, Rockland, Wareham and West Bridgewater contain the smallest. Good stands of the first quality may be found in all the towns, but Whitman, Scituate, Abington and Hanover are poorest in this respect. It may be stated here that these towns contain very little of the best quality of any of the different types.

Plymouth shows the highest proportion of forested land (82.5 per cent.), but there are several other towns containing 70 per cent. or more of forest growth. These towns are Carver, Hanover, Hanson, Kingston, Lakeville, Marion, Mattapoisett, Middleborough, Norwell, Pembroke and Plympton.

Brockton, Hingham, Marshfield, Scituate and Whitman have the smallest percentages of wooded areas.

The best oak is found in largest proportional quantities in Marion, Mattapoisett, Middleborough, Plymouth, Rochester and Scituate.

Maple is found mostly in cordwood sizes, but stands of firstclass stock may be found in Lakeville, Marion, Mattapoisett, Middleborough, Norwell, Pembroke, Rochester and Scituate.

The best stands of pitch pine occur in Carver, Duxbury, Kingston, Mattapoisett, Marion, Plymouth, Rochester and Wareham, all seacoast towns with the exception of Carver and Rochester, which are sandy plains.

Of the non-forest types West Bridgewater contains the highest proportion of agricultural land. Others of the larger culti- 
vated areas are Bridgewater, East Bridgewater, Hanover, Hingham, Scituate and Whitman.

Brockton and Whitman contain the largest proportional residential areas, although Plymouth and Middleborough have actual residential areas larger than Whitman.

Abington, Whitman and Hingham contain the largest proportional amount of pasture land.

Marshfield, Marion and Carver have large amounts of marsh land, Marshfield, as the name suggests, having by far the greatest area of this salt marsh.

The largest and best cranberry bogs are found in Carver and Wareham, while Lakeville contains more actual water area than any other town in the county.

\section{Moth Infestation.}

Since Plymouth County contains such a proportionately large amount of oak as compared to other sections of the State, we would naturally draw the conclusion that the moth infestation must be exceptionally large. This, however, is not true. Conditions here, with the exception of the town of Plymouth, are not much worse than those throughout the eastern part of Massachusetts, and at the present time the moth situation is such that, with careful supervision and a reasonable expenditure of money for spraying purposes, it may be kept well under control.

There are, however, large tracts of land forested with oak of poor quality, not large enough for cordwood and with little chance of being so for some years to come, that present a serious problem. These lots, most of them located in the southern part of the county, are situated far away from the centers, and on account of the poor quality of the wood, and its distance from a market, spraying is out of the question because of the expense entailed. These lots should be clean brushed and reforested with white or Scotch pine. The State forestry department has not at the present time the money to do this work, and anything that is attempted along this line must be done by the owners of the lands in question. 


\section{Forest Fire Protection.}

The destructive fires which have raged over the entire Cape country, including the southern part of Plymouth County, have caused very serious damage to forest growth. Indeed, fire has been the most serious enemy of timber propagation in this section. The geographic location of this part of the State, together with the high winds which prevail at certain periods of the year, are conditions which make each small brush fire a potential holocaust.

This fire menace has been recognized for a long time by the residents of the Cape counties and by the State Forester's department. A fire tower was constructed in Plymouth by that town in 1905. In 1911 the office of State Fire Warden was established, and since then towers have been erected on high points in the towns of Kingston, Hanson, Hingham and Middleborough. These towers, with the addition of that in Bourne in Barnstable County, now cover the entire area of Plymouth County, and statistics from the State Fire Warden's reports show that the fire damage in this section has been reduced about 75 per cent. since their erection.

\section{Forest Industries.}

The shoe manufacturing and cranberry raising industries require very large amounts of wood in the manufacture of boxes, crates and barrels for the shipment of their products. Practically all of the wood used is obtained from the county. In nearly every town may be found mills which saw 100,000 board feet or more of pine and oak each year. Many of these mills turn out the finished product, - boxes, crates, or barrels, as the case may be, - but a considerable number simply supply the boards, while others deliver their product in the form of shooks. The logs in almost all cases are cut short and bought locally by the cord, and are sawn into $\frac{5}{8}$-inch boards, which is the standard dimension for box boards.

In addition to the manufacture of boxes, etc., several of these sawmills do custom work, but there is nowhere near so much of this done now as in former years.

In one important respect the sawmills of Plymouth County differ from those located in other parts of the State. They are 
permanent. Logs are hauled to them by truck or shipped by rail. Were it not for the many destructive fires, the fact that these mills are permanent ones might have had a powerful effect in influencing the forest types.

Before a portable mill owner sets up his mill on a lot he must be sure that there are at least 200,000 feet of stock in the immediate vicinity that he can cut. Moving and setting up his mill to cut under that amount would hardly pay him unless the stock was exceptionally good.

When large tracts of land are cut over a change in forest conditions naturally results. New species, generally hardwoods, take the place of the old. These hardwoods, which grow very rapidly during their earlier years, shade and choke out the young reproduction of the conifers recently cut, and after a few years a stand of hardwoods, often of inferior quality, occupies the land formerly forested with pine or other valuable trees.

Where the mills are permanent, as in Plymouth County, the owner of a woodlot is not obliged to cut his lot clean. He can take out a few trees one year, haul them to the mill, and the following year cut out a few more.

When a stand is cut gradually in this way the type undergoes no serious change, since the reproduction is generally the same as the original trees.

To sum up the whole thing in a few words, permanent mills foster a system of selective cutting, and have a tendency to preserve the original species and types, while portable mills in many cases, through clean cutting, bring about a decided change in both.

Poplar makes an ideal wood for staves, and as an experiment the State Forest Commission has set out about 40,000 poplar cuttings on the State reservation in Carver.

White pine is the species most used in the manufacture of box boards, but of late years pitch pine is being substituted to some extent.

Stock for barrel staves is in some cases shipped from outside the State, some of it being loblolly pine from Virginia. Much of the stock, however, is obtained locally, and consists of pine and poplar with oak and maples for headings. Oak is used in the manufacture of piling and mine props. These products are used in the construction of docks, wharves, etc.

No attention has been given to cedar in the various tables, 
but nevertheless quite a little of this species is found in isolated sections of the county, and generally in swamps. This wood is used in the manufacture of shingles, and on rare occasions for barrels. It is also used for posts and poles.

The manufacture of lobster pots may be classed as a special industry. Oak and white pine are used in this product, and there are several concerns engaged in their manufacture.

Some years ago charcoal was produced in large quantities in various parts of Plymouth County. This industry has practically disappeared. Last year this department undertook the manufacture of charcoal as an experiment in the town of Mashpee. The lot was made up entirely of oak of poor quality and small size class, and the wood was too far away from a market to be put profitably into cordwood. Three pits were maintained, and about 40,000 bushels of charcoal were produced. It was thought that charcoal made from oak would not sell readily, but no trouble was experienced in disposing of the entire production in near-by towns; in fact, double the quantity could easily have been gotten rid of. In this experiment about 40 bushels of charcoal were produced from each cord of wood.

Mashpee is not a town in Plymouth County, and therefore these remarks are somewhat irrelevant, but they are made because of the fact that scattered throughout Plymouth County are hundreds of acres of scraggly oak and pine too far away from a market to be cut profitably for fuel, which the results of the experiment cause us to believe could be burned for charcoal and disposed of for at least a small profit. So far as we know there is but one man in the county engaged in the manufacture of charcoal at the present time. A bulletin containing more detailed information in regard to this experiment will be issued from the office of the State Forester in the near future.

Other forest products of Plymouth County are pin wood, mallet heads, ship timbers, wagon stock and hardwood rollers.

In this bulletin is included a list of the sawmill operators of the county, which gives information regarding their production, stock used, etc. This list is as complete as it was possible for us to make it in the limited time we had at our disposal.

Following are the percentage sheets of 26 towns in the county. The town of Hull was not considered at all in making the survey, as there is not enough wood growth there to war- 
rant it. These tables show the proportion of forest land to non-forest land, and also the relative proportions of the individual types of the forested areas. The tables alone could not be made to show the proportion of the separate type size classes, so they have been supplemented by diagrams from which may be formed an idea of the relative amounts of merchantable and non-merchantable timber of each type in each town. In these diagrams the proportion of non-merchantable sizes is represented by the inked portion of each line.

In arranging these diagrams size classes 1 and 2 of the white pine and pitch pine types were combined and classed as merchantable, while in the remainder of the types classes 1,2 and 3 were combined and classified in the same way. The remainder of the size classes was combined in each type and classed as non-merchantable. It will be noticed from this explanation that in the case of the hardwoods and mixed hardwoods and pine, class 3, or cordwood class, has been listed as merchantable, while in the case of the pines only classes 1 and 2 , containing lumber large enough for saw logs, were so listed.

\section{Forest Types and Acreage in 26 Towns in Plymouth County.}

\begin{tabular}{|c|c|c|c|c|c|c|c|c|c|c|}
\hline & & & \multicolumn{5}{|c|}{ Approximate Size Classes. } & \multirow{2}{*}{ Total. } & \multicolumn{2}{|c|}{ Per Cent. } \\
\hline & & & 1 & 2 & 3 & 4 & 5 & & Forest. & Town. \\
\hline \multicolumn{3}{|c|}{ Forest Trpes. } & Acres. & Acres. & Acres. & Acres. & Acres. & Acres. & & \\
\hline Pine, . & & & 4,184 & 5,862 & 6,439 & 3,747 & 2,126 & 22,358 & 7.4 & - \\
\hline Pine and oak, . & & . & 6,612 & 8,678 & 18,529 & 15,004 & 8,930 & 57,753 & 19.0 & - \\
\hline Pine and maple, & & . & 2,362 & 3,654 & 5,613 & 3,593 & 836 & 16,058 & 5.3 & - \\
\hline Oak type, . & & . & 5,337 & 9,956 & 24,615 & 30,669 & 24,321 & 94,898 & 31.2 & - \\
\hline Maple type, . & • & . & 1,101 & 6,282 & 15,048 & 19,215 & 5,652 & 47,298 & 15.5 & - \\
\hline Pitch pine type, & & . & 1,879 & 4,126 & 8,501 & 11,271 & 39,991 & 65,768 & 21.6 & - \\
\hline Total, . & - & • & 21,475 & 38,558 & 78,745 & 83,499 & 81,856 & 304,133 & - & 69.1 \\
\hline Per cent., . & - & . & 7.1 & 12.7 & -25.8 & 27.5 & 26.9 & & 100.0 & - \\
\hline \multicolumn{8}{|c|}{ Non-Forest TyPes. } & 67,612 & - & 15.3 \\
\hline Pasture, . & • & . & . & . & . & . & . & 16,607 & - & 3.8 \\
\hline Residential, . & . & . & . & . & . & . & . & 18,565 & - & 4.2 \\
\hline Water,.. . & . & . & . & . & . & . & . & 14,101 & - & 3.2 \\
\hline Cranberry bog, & . & . & . & . & . & . & . & 8,550 & - & 1.9 \\
\hline Marsh, . . . & . & - & . & . & . & . & . & 10,998 & - & 2.5 \\
\hline \multicolumn{3}{|c|}{ Total area of 26 towns, } & . & . & . & . & . & 440,566 & - & 100.0 \\
\hline
\end{tabular}




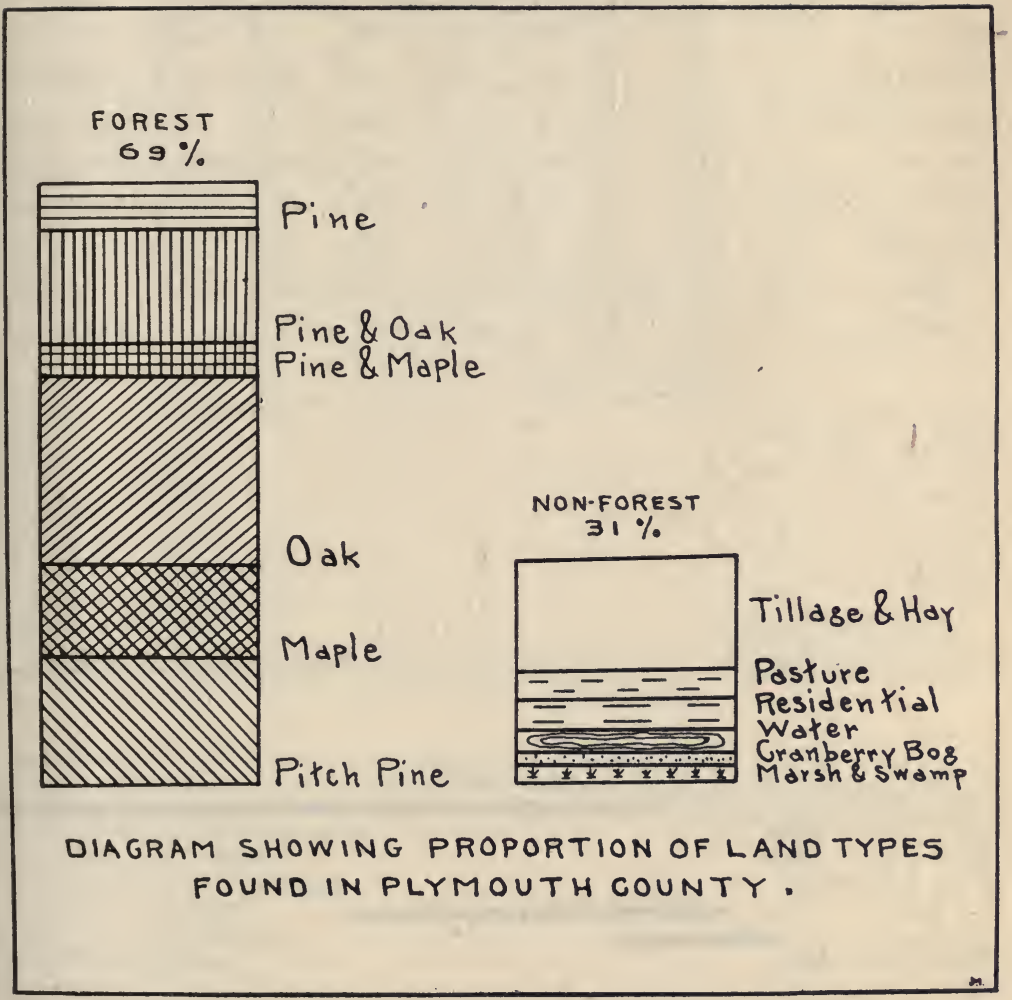


Abington.

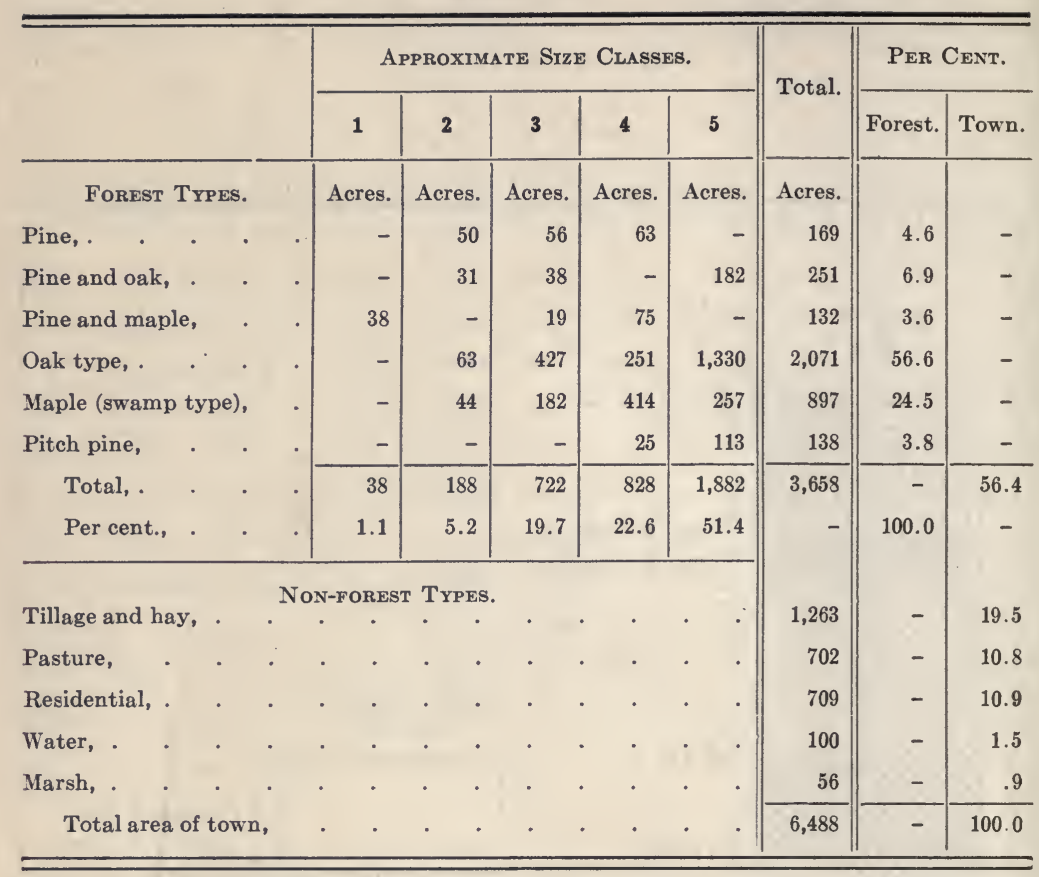

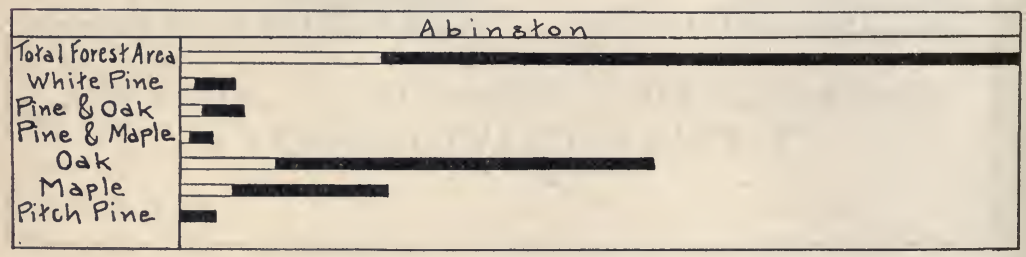

Merchantable Non-merchantable 
Bridgewater.

\begin{tabular}{|c|c|c|c|c|c|c|c|c|c|c|}
\hline & & & \multicolumn{5}{|c|}{ Approximate Size Classes. } & \multirow{2}{*}{ Total. } & \multicolumn{2}{|c|}{ Per Centr. } \\
\hline & & & 1 & 2 & 3 & 4 & 5 & & Forest. & Town. \\
\hline \multicolumn{3}{|c|}{ Forest TyPes. } & Acres. & Acres. & Acres. & Acres. & Acres. & Acres. & & \\
\hline Pine, . . & & & 202 & 185 & 330 & 174 & 856 & 1,747 & 15.4 & - \\
\hline Pine and oak, . & . & . & 121 & 318 & 659 & 572 & 885 & 2,555 & 22.6 & - \\
\hline Pine and maple, & . & . & 46 & 64 & 532 & 376 & 185 & 1,203 & 10.6 & - \\
\hline Oak type, . & . & . & 115 & 445 & 492 & 416 & 382 & 1,850 & 16.3 & - \\
\hline Maple (swamp) $t$ & type, & , & 40 & 162 & 625 & 1,319 & 752 & 2,898 & 25.6 & - \\
\hline Pitch pine, & . & . & - & - & 23 & 87 & 972 & 1,082 & 9.5 & - \\
\hline Total, . & . & . & 524 & 1,174 & 2,661 & 2,944 & 4,032 & 11,335 & - & 62.9 \\
\hline Per cent., . & . & 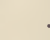 & 4.6 & 10.3 & 23.5 & 26 & 35.6 & - & 100.0 & - \\
\hline \multicolumn{8}{|c|}{ NoN-FOREST TYPES. } & 4,346 & - & 24.1 \\
\hline Pasture, & . & . & . & . & . & . & . & 839 & - & 4.7 \\
\hline Residential, . & . & - & . & . & . & . & . & 544 & - & 3.0 \\
\hline Water, . & . & . & . & . & . & . & . & 515 & - & 2.9 \\
\hline Marsh, . & . & . & . & . & . & . & . & 434 & - & 2.4 \\
\hline \multicolumn{3}{|c|}{ Total area of town, } & . & . & . & . & . & 18,013 & - & 100.0 \\
\hline
\end{tabular}

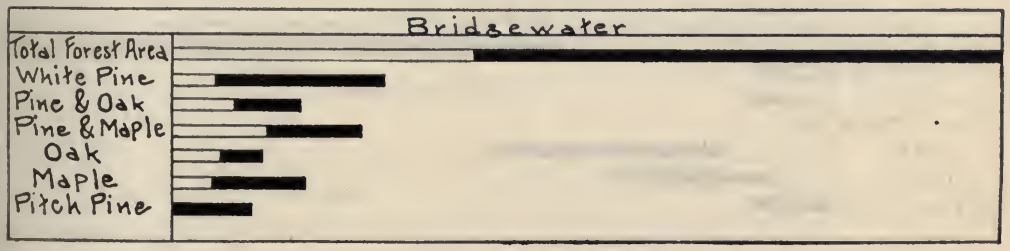




\section{BRockTON.}

\begin{tabular}{|c|c|c|c|c|c|c|c|c|c|c|}
\hline \multirow{2}{*}{ 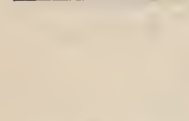 } & & & \multicolumn{5}{|c|}{ Approximate Size Crasses. } & \multirow{2}{*}{ Total. } & \multicolumn{2}{|c|}{ Per Centr. } \\
\hline & & & 1 & 2 & 3 & 4 & 5 & & Forest. & Town. \\
\hline \multicolumn{3}{|c|}{ Forest TrPes. } & Acres. & Acres. & Acres. & Acres. & Acres. & Acres. & & \\
\hline Pine, . & 1. & & 130 & 161 & 78 & 52 & 150 & 571 & 8.5 & - \\
\hline Pine and oak, . & . & . & 114 & 161 & 171 & 192 & 62 & 700 & 10.4 & - \\
\hline Pine and maple, & . & . & - & 83 & 150 & - & 52 & 285 & 4.2 & - \\
\hline Oak type, . & . & . & 130 & 228 & 638 & 830 & 907 & 2,733 & 40.5 & - \\
\hline Maple (swamp) $t$ & type, & . & - & 119 & 342 & 767 & 539 & 1,767 & 26.2 & - \\
\hline Pitch pine, & . & . & - & - & - & 83 & 601 & 684 & 10.2 & - \\
\hline Total, . & . & . & 374 & 752 & 1,379 & 1,924 & 2,311 & 6,740 & - & 49.1 \\
\hline Per cent., & . & . & 5.6 & 11.1 & 20.5 & 28.5 & 34.3 & - & 100.0 & - \\
\hline \multicolumn{8}{|c|}{ NON-FOREST TYPES. } & 2,411 & - & 17.5 \\
\hline Pasture, & . & . & . & . & . & . & . & 716 & - & 5.2 \\
\hline Residential, : & . & . & - & . & . & . & . & 3,733 & - & 27.1 \\
\hline Water, . & . & . & . & . & . & . & . & 21 & - & .2 \\
\hline Marsh, . . & $\cdot$ & : & . & . & . & . & . & 124 & - & .9 \\
\hline \multicolumn{3}{|c|}{ Total area of town, } & . & . & . & . & . & 13,745 & - & 100.0 \\
\hline
\end{tabular}

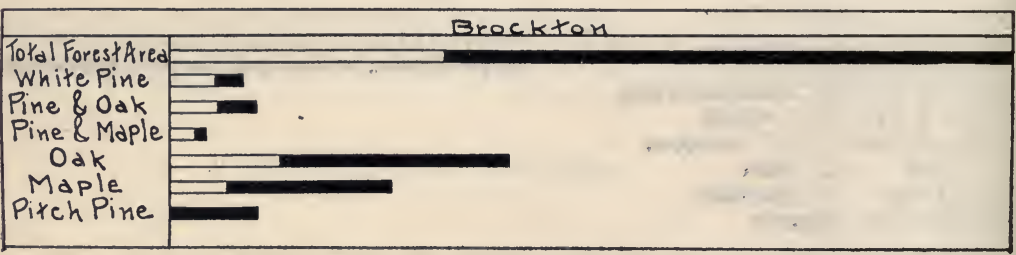


Carver.

\begin{tabular}{|c|c|c|c|c|c|c|c|c|c|c|}
\hline & 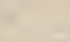 & & \multicolumn{5}{|c|}{ Approximate Size Cuasses. } & \multirow{2}{*}{ Total. } & \multicolumn{2}{|c|}{ Per Cent. } \\
\hline & & & 1 & 2 & 3 & 4 & 5 & & Forest. & Town. \\
\hline \multicolumn{3}{|c|}{ FoREst TYPES. } & Acres. & Acres. & Acres. & Acres. & Acres. & Acres. & & \\
\hline Pine, . & - & ${ }^{\circ}$ & 302 & 604 & 685 & 705 & - & 2,296 & 12.4 & - \\
\hline Pine and oak, . & . & - & - & 1,281 & 2,260 & 2,621 & - & 6,162 & 33.2 & - \\
\hline Pine and maple, & . & - & 163 & 1,016 & 846 & 622 & - & 2,647 & 14.3 & - \\
\hline Oak type, . . & • & . & 36 & 24 & 65 & 812 & - & 937 & 5.1 & - \\
\hline Maple (swamp) ty & ype, & - & 24 & 496 & 729 & 1,257 & - & 2,506 & 13.5 & - \\
\hline Pitch pine, & - & • & - & 314 & 500 & 3,181 & - & 3,995 & 21.5 & - \\
\hline Total, . & $\therefore$ & - & 525 & 3,735 & 5,085 & 9,198 & - & 18,543 & - & 73.2 \\
\hline Per cent., · & · & . & 2.8 & 20.1 & 27.4 & 49.7 & - & - & 100.0 & - \\
\hline \multicolumn{7}{|c|}{ NON-FOREST TrPES. } & . & 1,667 & - & 6.6 \\
\hline Pasture, . & $\cdot$. & . & . & . & . & . & . & 667 & - & 2.6 \\
\hline Residential, . & .. & . & . & . & - & . & . & 121 & - & .5 \\
\hline Water, . & - & . & . & . & . & . & . & 761 & - & 3.0 \\
\hline Cranberry bog, & . $\quad$. & . & . & . & . & . & . & 3,574 & - & 14.1 \\
\hline \multicolumn{3}{|c|}{ Total area of town, } & . & . & . & . & . & 25,333 & - & 100.0 \\
\hline
\end{tabular}

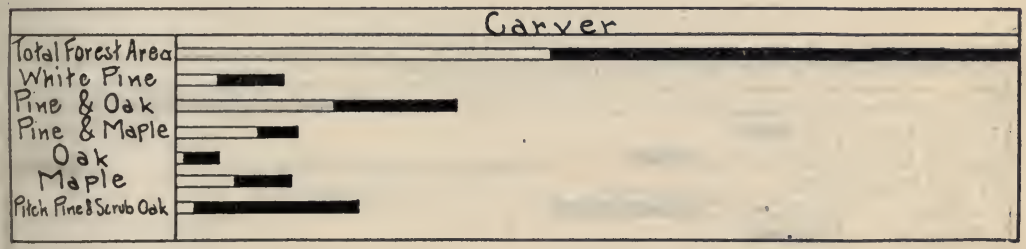


DUXBURY.

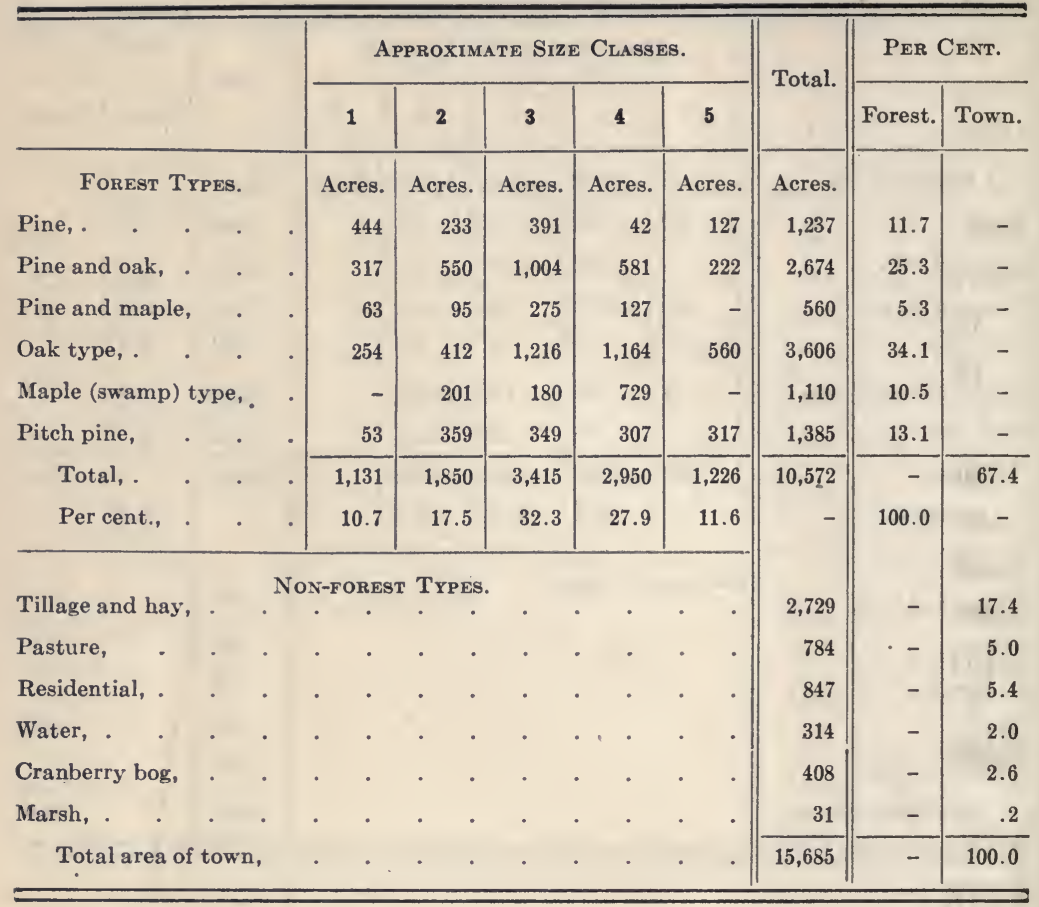

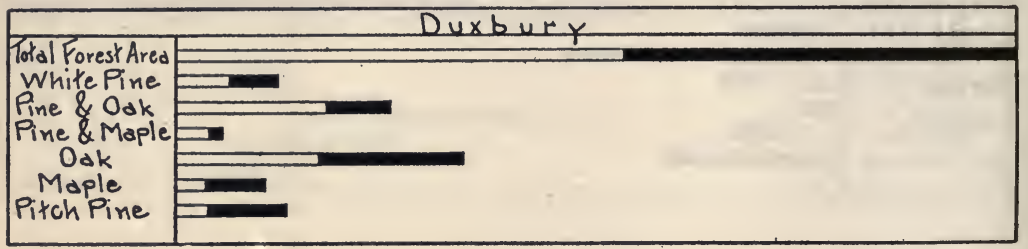


EAst Bridgewater.

\begin{tabular}{|c|c|c|c|c|c|c|c|c|c|c|}
\hline & & & \multicolumn{5}{|c|}{ Approximate Size Classes. } & \multirow{2}{*}{ Total. } & \multicolumn{2}{|c|}{ Per Cent. } \\
\hline t & & & 1 & 2 & 3 & 4 & 5 & & Forest. & Town. \\
\hline \multicolumn{3}{|c|}{ Forest TyPes. } & Acres. & Acres. & Acres. & Acres. & Acres. & Acres. & & \\
\hline Pine, . . & & - & 75 & 98 & 230 & 310 & 17 & 730 & 10.6 & - \\
\hline Pine and oak, . & . & & - & 40 & 184 & 252 & 396 & 872 & 12.7 & - \\
\hline Pine and maple, & . & . & - & - & 52 & 149 & - & 201 & 2.9 & - \\
\hline Oak type, . & . & . & 34 & 120 & 287 & 1,308 & 1,130 & 2,879 & 41.8 & - \\
\hline Maple (swamp) $t$ & type, & . & 23 & 161 & 361 & 689 & 625 & 1,859 & 26.9 & - \\
\hline Pitch pine, & . & . & - & - & 11 & - & 339 & 350 & 5.1 & - \\
\hline Total, . & . & . & 132 & 419 & 1,125 & 2,708 & 2,507 & 6,891 & - & 60.8 \\
\hline Per cent., . & . & . & 1.9 & 6.1 & 16.3 & 39.3 & 36.4 & - & 100.0 & - \\
\hline \multicolumn{8}{|c|}{ NON-FOREST TYPES. } & & & \\
\hline Tillage and hay, & . & - & $\cdot \quad \cdot$ & . $\quad$. & . & $\cdot$ & - & 3,284 & - & 28.9 \\
\hline Pasture, & . & . & . & . & . & . & . & 648 & - & 5.7 \\
\hline Residential, . & . & . & . & . & . & . & . & 270 & - & 2.4 \\
\hline Water, . & . & . & . & . & . & . & . & 143 & - & 1.3 \\
\hline Marsh, . & . & . & . & . & . & . & . & 103 & - & .9 \\
\hline \multicolumn{3}{|c|}{ Total area of town, } & . & . & . & . & . & 11,339 & - & 100.0 \\
\hline
\end{tabular}

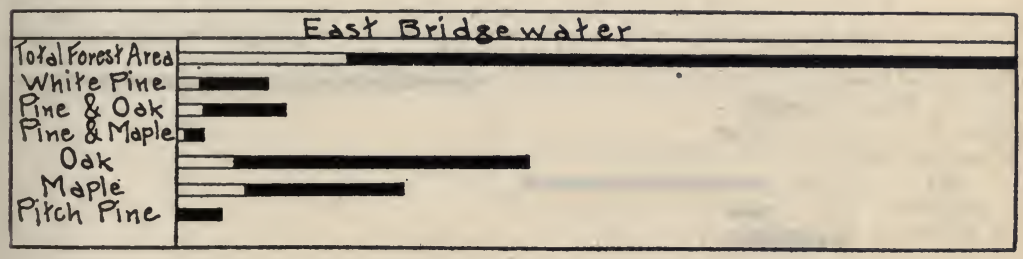


Halifax.

\begin{tabular}{|c|c|c|c|c|c|c|c|c|c|c|}
\hline & & & \multicolumn{5}{|c|}{ Approximate Size Classes. } & \multirow{2}{*}{ Total. } & \multicolumn{2}{|c|}{ Per Cent. } \\
\hline & & & 1 & 2 & 3 & 4 & 5 & & Forest. & Town. \\
\hline \multicolumn{3}{|c|}{ FOREST TYPES. } & Acres. & Acres. & Acres. & Acres. & Acres. & Acres. & & \\
\hline Pine, . . . & . & . & 139 & 278 & 285 & 110 & 102 & 914 & 12.5 & - \\
\hline Pine and oak, . & . & . & 22 & 22 & 922 & - & 146 & 1,112 & 15.2 & - \\
\hline Pine and maple, & . & . & - & 102 & 241 & - & - & 343 & 4.7 & - \\
\hline Oak type, . & . & . & - & 66 & 666 & 878 & 1,222 & 2,832 & 38.7 & - \\
\hline Maple (swamp) & type, & $\cdot$ & - & 44 & 644 & 322 & 51 & 1,061 & 14.5 & - \\
\hline Pitch pine, & . & . & - & - & - & - & 1,053 & 1,053 & 14.4 & - \\
\hline Total, . & · & - & 161 & 512 & 2,758 & 1,310 & 2,574 & 7,315 & - & 65.8 \\
\hline Per cent., . & · & . & 2.2 & 7 & 37.7 & 17.9 & 35.2 & - & 100.0 & - \\
\hline Tillage, . & · &.$^{\text {No }}$ & N-FOREST & TYPes. & · & - & - & 1,857 & - & 16.7 \\
\hline Pasture, . & . & . & - & - & . & . & . & 278 & - & 2.5 \\
\hline Residential, . & . & - & · & . & . & . & . & 89 & - & .8 \\
\hline Water, . & . & - & - & ·. & . & . & . & 889 & - & 8.0 \\
\hline Cranberry bog, & . & - & . & . & . & . & - & 222 & - & 2.0 \\
\hline Marsh, . . & . & . & . & . & . & . & . & 467 & - & 4.2 \\
\hline \multicolumn{3}{|c|}{ Total area of town, } & . & . & . & . & - & 11,117 & - & 100.0 \\
\hline
\end{tabular}

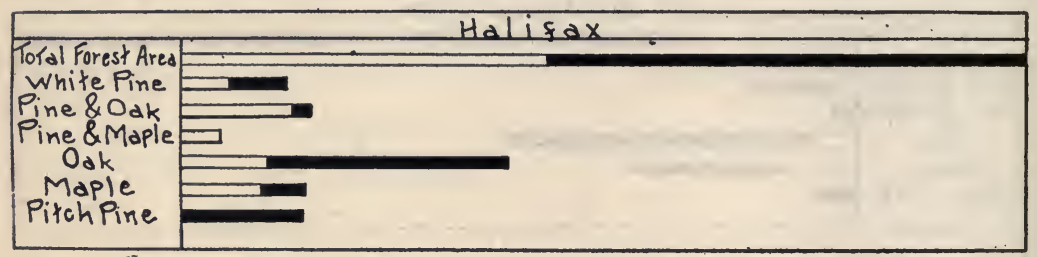


Hanover.

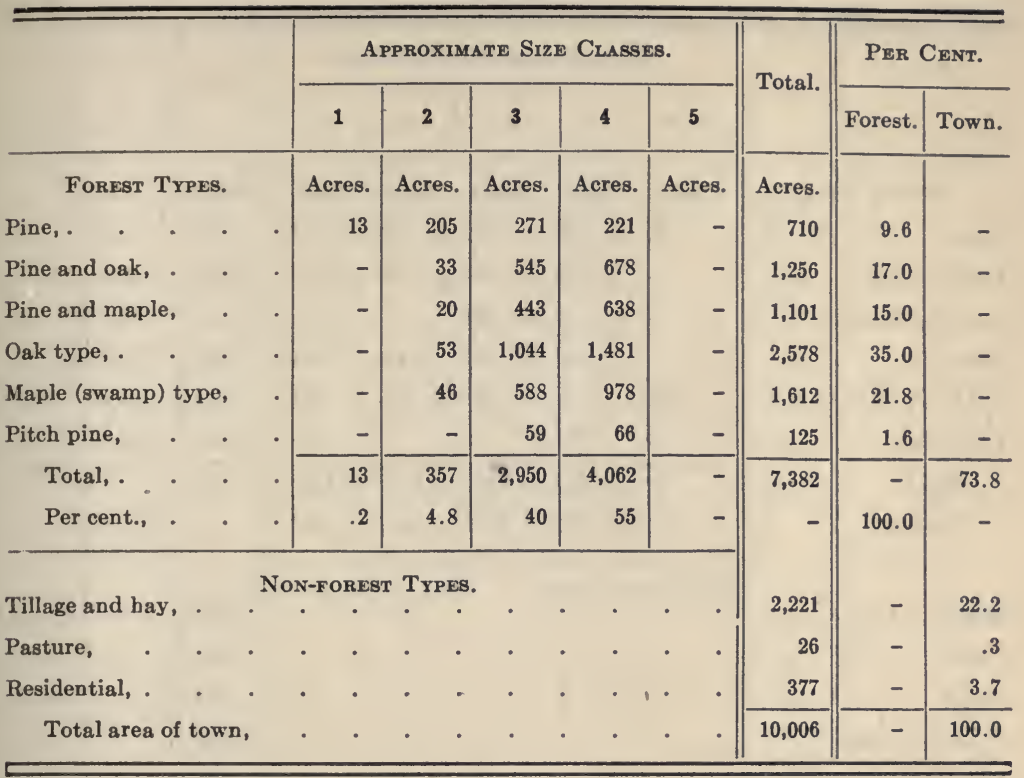

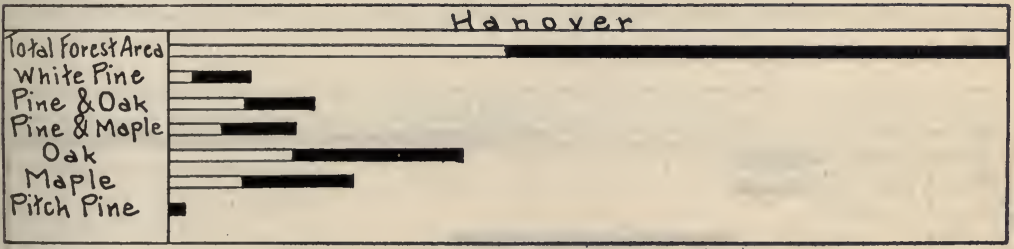


Hanson.

\begin{tabular}{|c|c|c|c|c|c|c|c|c|c|}
\hline & & \multicolumn{5}{|c|}{ Approximate Size Classes. } & \multirow{2}{*}{ Total. } & \multicolumn{2}{|c|}{ Per Cent. } \\
\hline & & 1 & 2 & 3 & 4 & 5 & & Forest. & Town. \\
\hline \multicolumn{2}{|l|}{ Forest Tripes. } & Acres. & Acres. & Acres. & Acres. & Acres. & Acres. & & \\
\hline Pine, . & . & 69 & 176 & 195 & 365 & 63 & 868 & 12.3 & - \\
\hline Pine and oak, . & . & - & 19 & 208 & 309 & 391 & 927 & 13.1 & - \\
\hline Pine and maple, & . & - & 19 & 208 & - & - & 227 & 3.2 & - \\
\hline Oak type, . & . & - & 290 & 788 & 1,430 & 800 & 3,308 & 47.0 & - \\
\hline Maple (swamp) type, & . & 82 & 38 & 586 & 668 & 189 & 1,563 & 22.2 & - \\
\hline Pitch pine, & . & - & - & - & - & 158 & 158 & 2.2 & - \\
\hline Total, . & - & 151 & 542 & 1,985 & 2,772 & 1,601 & 7,051 & - & 70 \\
\hline Per cent., . . & . & 2.1 & 7.7 & 28.2 & 39.3 & 22.7 & - & 100.0 & - \\
\hline Tillage and hay, : & & $\begin{array}{c}\text { N-FORES } \\
\cdot\end{array}$ & $\begin{array}{l}\text { TYPES. } \\
0\end{array}$ & • & $\cdot$ & . & 1,655 & - & 16.3 \\
\hline Pasture, . . & . & . & . & . & . & . & 422 & - & 4.2 \\
\hline Water, . & • & - & . & - & . & . & 479 & - & 4.6 \\
\hline Cranberry bog, & . & . & - & . & . & . & 265 & - & 2.6 \\
\hline Marsh, . . . & • & - & . & . & . & . & 252 & - & 2.3 \\
\hline Total area of town, & & . & . & . & · & . & 10,124 & - & 100.0 \\
\hline
\end{tabular}

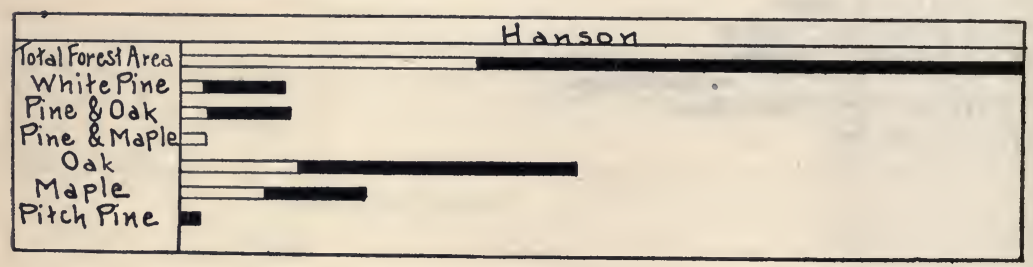


HiNGHAM.

\begin{tabular}{|c|c|c|c|c|c|c|c|c|c|c|}
\hline & & & \multicolumn{5}{|c|}{ Approximate Size Classes. } & \multirow{2}{*}{ Total. } & \multicolumn{2}{|c|}{ Per Cent. } \\
\hline & \multicolumn{2}{|c|}{-} & 1 & 2 & 3 & 4 & 5 & & Forest. & Town. \\
\hline \multicolumn{3}{|c|}{ Forest Types. } & Acres. & Acres. & Acres. & Acres. & Acres. & Acres. & & \\
\hline Pine, . & . & . & 190 & 318 & 310 & 554 & - & 1,372 & 19.2 & - \\
\hline Pine and oak, . & . & . & 18 & 123 & 617 & 541 & - & 1,299 & 18.1 & - \\
\hline Pine and maple, & . & . & 49 & 80 & 257 & 154 & - & 540 & 7.5 & - \\
\hline Oak type, . & . & . & 209 & 263 & 445 & 1,473 & - & 2,390 & 33.4 & - \\
\hline Maple (swamp) $t$ & type, & $\cdot$ & - & 116 & 331 & 938 & - & 1,385 & 19.3 & - \\
\hline Pitch pine, & .. & $\cdot$ & . & - & - & 178 & - & 178 & 2.5 & - \\
\hline Total, . & - & $\cdot$ & 466 & 900 & 1,960 & 3,838 & - & 7,164 & - & 49.6 \\
\hline Per cent., & . & $\cdot$ & 6.5 & 12.6 & 27.4 & 53.5 & - & - & 100.0 & - \\
\hline \multicolumn{8}{|c|}{ NON-FOREST TYPES. } & 3,243 & - & 22.4 \\
\hline Pasture, . & · & . & . & . & . & . & - & 2,421 & - & 16.8 \\
\hline Residential, . & . & . & . & . & . & . & . & 1,416 & - & 9.8 \\
\hline Water, . & . & . & . & . & . & - & . & 161 & - & 1.1 \\
\hline Marsh, . & · & - & . & . & . & . & . & 49 & - & .3 \\
\hline \multicolumn{3}{|c|}{ Total area of town, } & . & . & - & . & . & 14,454 & - & 100.0 \\
\hline
\end{tabular}

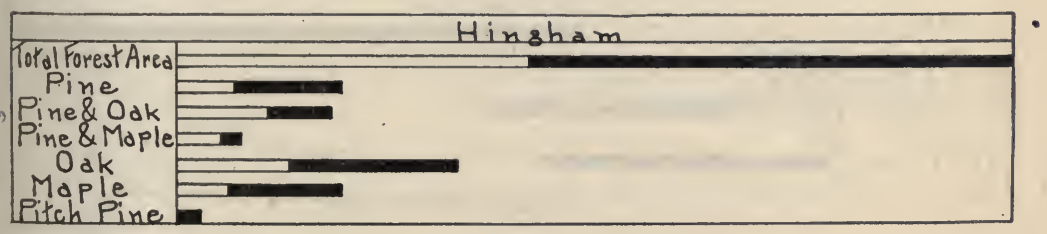


Kingston.

\begin{tabular}{|c|c|c|c|c|c|c|c|c|c|c|}
\hline & & & \multicolumn{5}{|c|}{ Approximate, Size Classes. } & \multirow{2}{*}{ Total. } & \multicolumn{2}{|c|}{ Per Cent. } \\
\hline & & & 1. & 2 & 3 & 4 & 5 & & Forest. & Town. \\
\hline \multicolumn{3}{|c|}{ Forest TYPES. } & Acres. & Acres. & Acres. & Acres. & Acres. & Acres. & & \\
\hline Pine, . . & . & $\because$ & 270 & 235 & 165 & 78 & 139 & 887 & 10.2 & - \\
\hline Pine and oak, . & . & . & 96 & 314 & 270 & - & 44 & 724 & 8.3 & - \\
\hline Oak type, . & . & . & 148 & 61 & 1,019 & 853 & 1,602 & 3,683 & 42.3 & - \\
\hline Maple (swamp) $t$ & pe, & . & - & 131 & 78 & - & 70 & 279 & 3.2 & - \\
\hline Pitch pine, & & . & 113 & - & 627 & 183 & 2,213 & 3,136 & 36.0 & - \\
\hline Total, . & . & . & 627 & 741 & 2,159 & 1,114 & 4,068 & 8,709 & - & 71.5 \\
\hline Per cent., . & . & . & 7.2 & 8.5 & 24.8 & 12.8 & 46.7 & - & 100.0 & - \\
\hline \multicolumn{8}{|c|}{ NON-FOREST TYPES. } & 2,107 & - & 17.3 \\
\hline Pasture, & . & . & . & . & . & . & . & 97 & - & .8 \\
\hline Residential, . & . & . & . & . & . & . & . & 780 & - & 6.4 \\
\hline Water, . & . & . & . & - & . & . & . & 341 & - & 2.8 \\
\hline Cranberry bog; & . & - & . & . & . & . & . & 146 & - & 1.2 \\
\hline \multicolumn{3}{|c|}{ Total area of town, } & . & . & . & . & . & 12,180 & - & 100.0 \\
\hline
\end{tabular}

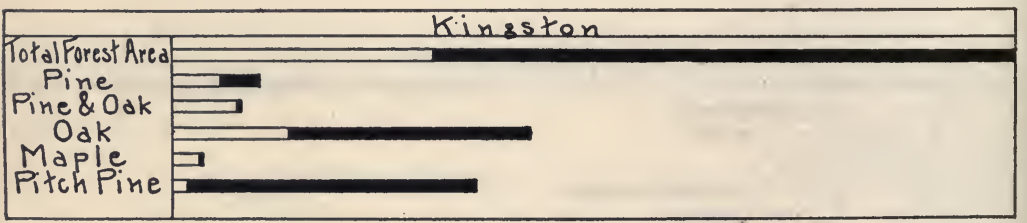


LAKEVILLE.

\begin{tabular}{|c|c|c|c|c|c|c|c|c|c|c|}
\hline & & & \multicolumn{5}{|c|}{ Approximate Size Classes. } & \multirow{2}{*}{ Total. } & \multicolumn{2}{|c|}{ Per Cent. } \\
\hline & & & 1 & 2 & 3 & 4 & 5 & & Forest. & Town. \\
\hline \multicolumn{3}{|c|}{ FoRest TrPes. } & Acres. & Acres. & Acres. & Acres. & Acres. & Acres. & & 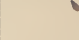 \\
\hline Pine, . $\quad$. & • & - & 134 & 652 & 284 & 200 & - & 1,270 & 7.6 & - \\
\hline Pine and oak, . & · & . & 351 & 819 & 919 & 718 & 551 & 3,358 & 20.1 & - \\
\hline Pine and maple, & . & . & 117 & 167 & 100 & 33 & 33 & 450 & 2.7 & - \\
\hline Oak type, . & $\cdot$ & . & 635 & 752 & 1,570 & 1,704 & 3,074 & 7,735 & 46.3 & - \\
\hline Maple (swamp) ty & ype, & . & 234 & 635 & 1,672 & 535 & 551 & 3,627 & 21.7 & - \\
\hline Pitch pine, & • & . & - & 33 & 84 & 150 & - & 267 & 1.6 & - \\
\hline Total, . & . & . & 1,471 & 3,058 & 4,629 & 3,340 & 4,209 & 16,707 & - & 72.2 \\
\hline Per cent., . & . & - & 8.8 & 18.3 & 27.7 & 20 & 25.2 & - & 100.0 & - \\
\hline \multicolumn{8}{|c|}{ NON-FOREST TYPES. } & 3,286 & - & 14.2 \\
\hline Pasture, $\quad$. & : & . & . & · & . & · & · & 1,157 & - & 5.0 \\
\hline Residential, . & $\dot{.}$ & . & . & . & . & · & . & 370 & - & 1.6 \\
\hline Water, . & . & . & . & . & - & - & . & 1,134 & - & 4.9 \\
\hline Cranberry bog, & - & - & . & . & - & . & • & 417 & - & 1.8 \\
\hline Marsh, . · & $\cdot$ & - & • & - & - & - & . & 69 & - & .3 \\
\hline Total area of & town, & & . & . & - & , & . & 23,140 & - & 100.0 \\
\hline
\end{tabular}

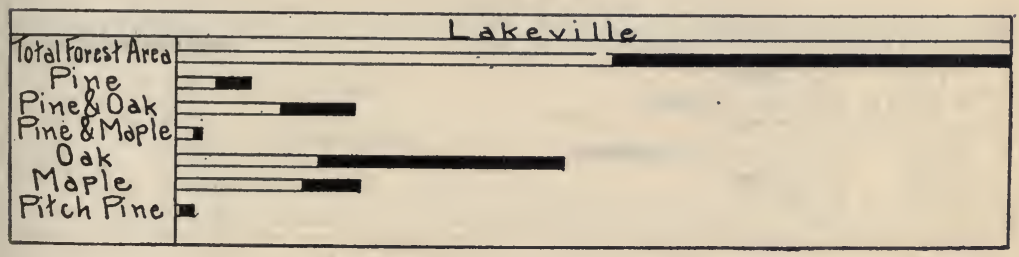


MARION.

\begin{tabular}{|c|c|c|c|c|c|c|c|c|c|c|}
\hline & & & \multicolumn{5}{|c|}{ Approximate Size Cuasses. } & \multirow{2}{*}{ Total. } & \multicolumn{2}{|c|}{ Per Cent. } \\
\hline & & & 1 & 2 & 3 & 4 & 5 & & Forest. & Town. \\
\hline \multicolumn{3}{|c|}{ FOREST TrPES. } & Acres. & Acres. & Acres. & Acres. & Acres. & Acres. & \multirow[b]{2}{*}{13.4} & \multirow[b]{2}{*}{-} \\
\hline Pine, . . . & . & & 371 & 185 & 282 & 62 & 21 & 921 & & \\
\hline Pine and oak, . & . & & 791 & 282 & 185 & 247 & 27 & 1,532 & 22.3 & - \\
\hline Pine and maple, & . & 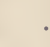 & 502 & 117 & 130 & 27 & - & 776 & 11.3 & - \\
\hline Oak type, . . & . & 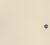 & 185 & 825 & 453 & 453 & 295 & 2,211 & 32.2 & - \\
\hline Maple (swamp) $t$ & type, & & 82 & 151 & 419 & 137 & 110 & 899 & 13.1 & - \\
\hline \multirow{2}{*}{$\begin{array}{c}\text { Pitch pine, } \\
\text { Total, . }\end{array}$} & : & . & 89 & 337 & 103 & - & - & 529 & 7.7 & - \\
\hline & . & & 2,020 & 1,897 & 1,572 & 926 & 453 & \multirow{3}{*}{$\begin{array}{r}6,868 \\
-\end{array}$} & \multirow{2}{*}{$\begin{array}{c}- \\
100.0\end{array}$} & \multirow{2}{*}{$\begin{array}{r}75 \\
-\end{array}$} \\
\hline Per cent., . & . & 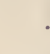 & 29.4 & 27.6 & 22.9 & 13.5 & 6.6 & & & \\
\hline \multicolumn{8}{|c|}{ NON-FOREST TYPES. } & & \multicolumn{2}{|r|}{3.7} \\
\hline Pasture, . & . & . & . & . & . & . & . & 117 & - & 1.3 \\
\hline Residential, . & · & . & . & - & . & . & . & 618 & - & 6.8 \\
\hline Water, . & . & . & . & . & . & . & . & 268 & - & 2.9 \\
\hline Cranberry bog, & . & . & . & . & . & . & . & 206 & - & 2.2 \\
\hline Marsh, . . & · & . & . & . & . & . & . & 744 & - & 8.1 \\
\hline Total area of & town & & . & . & . & . & . & 9,157 & - & 100.0 \\
\hline
\end{tabular}

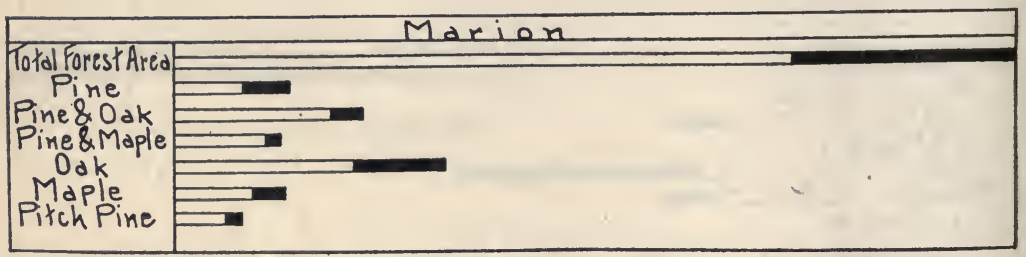




\section{Marshfield.}

\begin{tabular}{|c|c|c|c|c|c|c|c|c|c|c|}
\hline & & \multicolumn{5}{|c|}{ Approximate Size Classes. } & \multirow{2}{*}{ Total. } & \multicolumn{2}{|c|}{ Per Cent. } \\
\hline & & & 1 & 2 & 3 & 4 & 5 & & Forest. & Town. \\
\hline \multicolumn{2}{|c|}{ FOREST TYPES. } & & Acres. & Acres. & Acres. & Acres. & Acres. & Acres. & \multirow[b]{2}{*}{6.4} & \multirow[b]{2}{*}{ - } \\
\hline Pine, . · . & . & & 135 & 242 & 72 & 81 & 45 & 575 & & \\
\hline Pine and oak, . & & - & 207 & 207 & 817 & 673 & 386 & 2,290 & 25.5 & - \\
\hline Pine and maple, & & • & - & 81 & 242 & .36 & 18 & 377 & 4.2 & - \\
\hline Oak type, . & • & • & 54 & 242 & 1,015 & 835 & 512 & 2,658 & 29.6 & - \\
\hline Maple (swamp) $t_{3}$ & ype, & • & - & - & 1,131 & 422 & 368 & 1,921 & 21.4 & - \\
\hline Pitch pine, & & . & - & 45 & 494 & 269 & 350 & 1,158 & 12.9 & - \\
\hline Total, . & & . & 396 & 817 & 3,771 & 2,316 & 1,679 & 8,979 & - & 49.2 \\
\hline Per cent., . & & & 4.4 & 9.1 & 42 & 25.8 & 18.7 & - & 100.0 & - \\
\hline \multicolumn{8}{|c|}{ NON-FOREST TYPES. } & 3,358 & \multicolumn{2}{|r|}{18.4} \\
\hline Pasture, . & . & & . & . & . & . & . & 839 & - & 4.6 \\
\hline Residential, . & - & & . & . & . & . & . & 986 & - & 5.4 \\
\hline Water, . & - & & - & - & - & . & . & 292 & - & 1.6 \\
\hline Cranberry bog, & - & & - & - & . & - & - & 91 & - & .5 \\
\hline Marsh, . & - & & - & - & - & - & . & 3,705 & - & 20.3 \\
\hline Total area of & town & & - & . & - & . & . & 18,250 & - & 100.0 \\
\hline
\end{tabular}

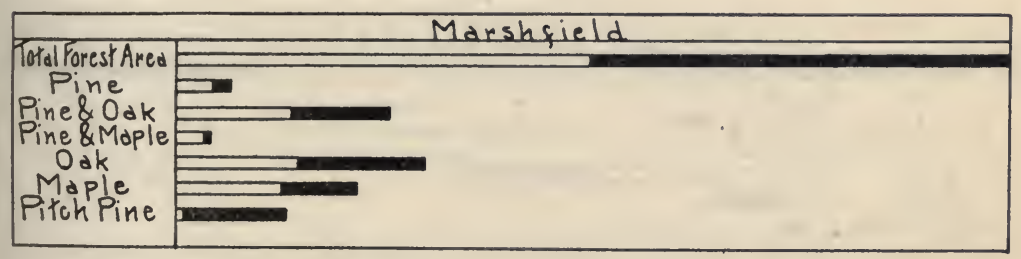


Mattapoisett.

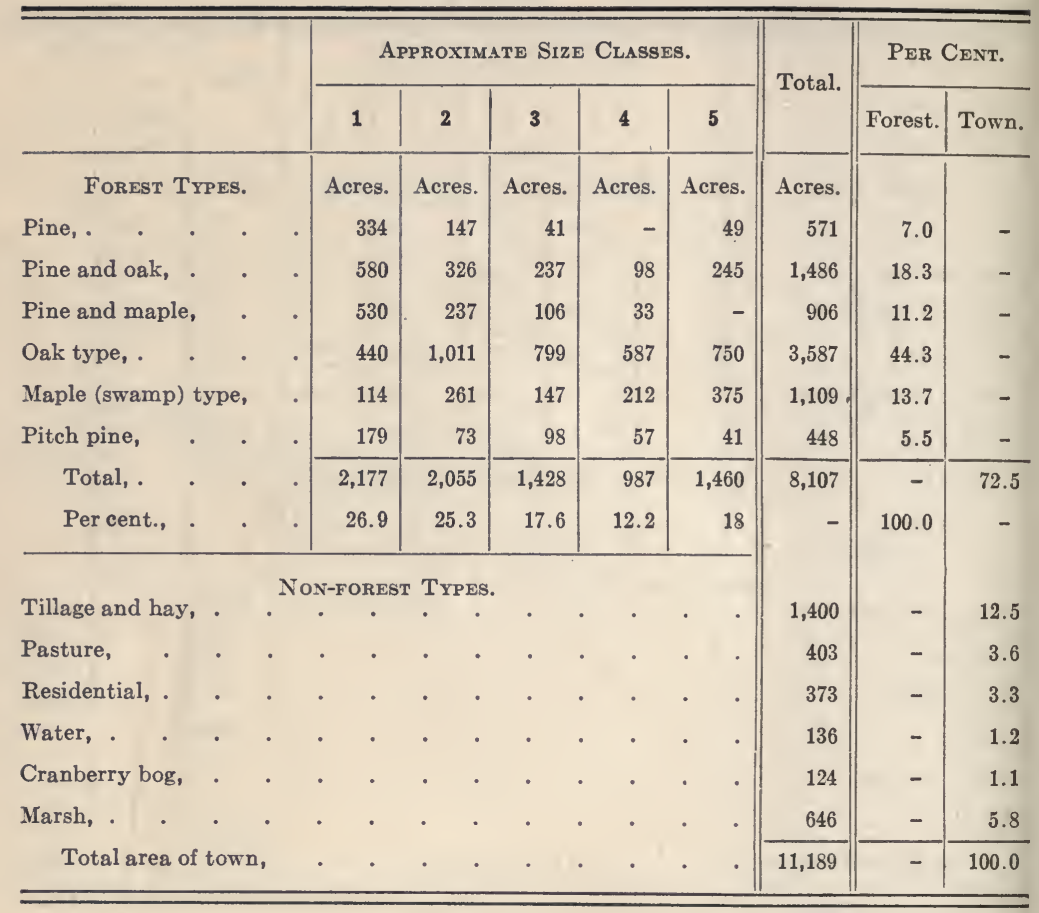

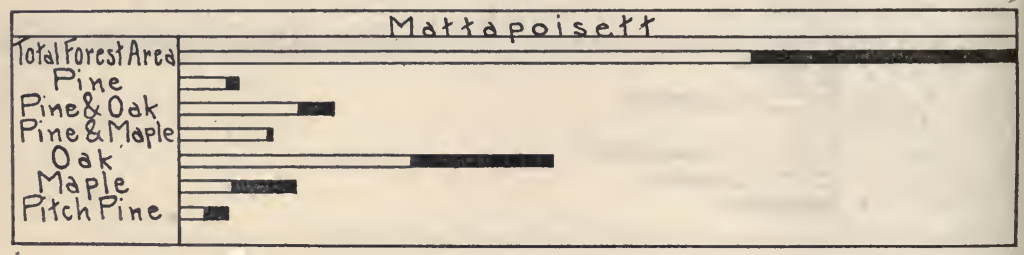


Middeborough.

\begin{tabular}{|c|c|c|c|c|c|c|c|c|c|c|}
\hline & & & \multicolumn{5}{|c|}{ Approximate Size Classes. } & \multirow{2}{*}{ Total. } & \multicolumn{2}{|c|}{ Per Cent. } \\
\hline & & & 1 & 2 & 3 & 4 & 5 & & Forest. & Town. \\
\hline \multicolumn{3}{|c|}{ Forest Types. } & Acres. & Acres. & Acres. & Acres. & Acres. & Acres. & 1 & \\
\hline \multicolumn{11}{|c|}{ Pine, . . . . } \\
\hline \multicolumn{9}{|c|}{ Pine and maple, . } & 25.4 & - \\
\hline Oak type, . & . & & $679^{-}$ & 1,332 & 4,969 & 8,347 & -1 & 15,327 & 43.3 & - \\
\hline \multicolumn{3}{|c|}{ Maple (swamp) type, } & 130 & 1,951 & 3,444 & 5,195 & -1 & 10,720 & 30.3 & - \\
\hline Pitch pine, & . & • & 10 & 108 & 79 & 145 & -1 & 342 & 1.0 & - \\
\hline Total, . & . $\quad$. & . & 2,184 & 4,588 & 11,435 & 17,186 & - & 35,393 & - & 75.8 \\
\hline Per cent., . & . . & & 6.2 & 13 & 32.3 & 48.5 & - & - & 100.0 & - \\
\hline Tillage and hay, & , & \multicolumn{4}{|c|}{ NON-FOREST TYPEs. } & . & . & 8,187 & - & 17.5 \\
\hline Pasture, $\quad$. & - & . & . & . & . & . & . & 1,770 & - & 3.8 \\
\hline Residential, . & . & . & . & . & . & . & . & 785 & - & 1.7 \\
\hline Water, . & · & . & . & . & . & . & - & 511 & - & 1.1 \\
\hline Marsh, . . & · & . & - & - & . & - & - & 44 & - & .1 \\
\hline \multicolumn{3}{|c|}{ Total area of town, } & . & . & . & : & . & 46,690 & - & 100.0 \\
\hline
\end{tabular}

1 Size classes 4 and 5 have been combined.

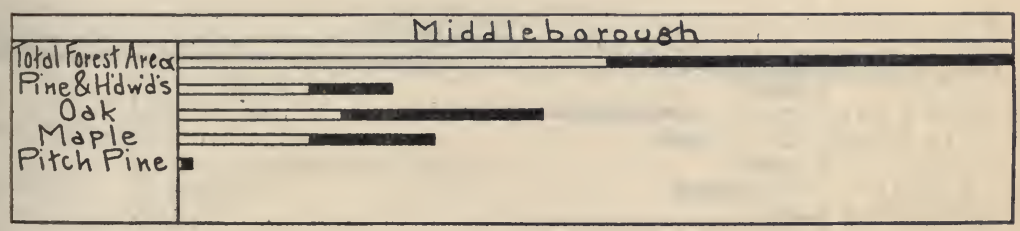


Norwell.

\begin{tabular}{|c|c|c|c|c|c|c|c|c|c|c|}
\hline & & & \multicolumn{5}{|c|}{ Approximate Size Classes. } & \multirow{2}{*}{ Total. } & \multicolumn{2}{|c|}{ Per Cent. } \\
\hline & & & 1 & 2 & 3 & 4 & 5 & & Forest. & Town. \\
\hline \multicolumn{3}{|c|}{ Forest TYPES. } & Acres. & Acres & Acres. & Acres. & Acres. & Acres. & & \\
\hline Pine, . . & . $\quad$. & . & 89 & 160 & 594 & 217 & 32 & 1,092 & 10.4 & - \\
\hline Pine and oak, . & . $\quad$. & . & 141 & 467 & 971 & 1,457 & 697 & 3,733 & 35.7 & - \\
\hline Pine and maple, & . & . & 77 & 550 & 901 & 556 & 102 & 2,186 & 20.9 & - \\
\hline Oak type, . . & . & . & 77 & 134 & 294 & 262 & 217 & 984 & 9.4 & - \\
\hline Maple (swamp) $t$ & type, & . & 26 & 326 & 435 & 658 & 300 & 1,745 & 16.6 & - \\
\hline Pitch pine, & .. & . & - & - & 300 & 192 & 243 & 735 & 7.0 & - \\
\hline Total, . & . & . & 410 & 1,637 & 3,495 & 3,342 & 1,591 & 10,475 & - & 76.7 \\
\hline Per cent., . & . & . & 3.9 & 15.6 & 33.4 & 31.9 & 15.2 & - & 100.0 & - \\
\hline \multicolumn{8}{|c|}{ NON-FOREST TYPES. } & 2,443 & - & 17.9 \\
\hline Pasture, . & . & . & . & . & . & . & . & 211 & - & 1.5 \\
\hline Residential, . & . & . & - & . & - & . & . & 89 & - & .7 \\
\hline Water, · & . & . & . & . & . & . & . & 51 & - & .4 \\
\hline Cranberry bog, & . & . & . & . & . & . & . & 13 & - & .1 \\
\hline Marsh, . . & · & . & . & . & . & . & . & 371 & - & 2.7 \\
\hline \multicolumn{3}{|c|}{ Total area of town, } & - & $\cdot$ & - & - & - & 13,653 & - & 100.0 \\
\hline
\end{tabular}

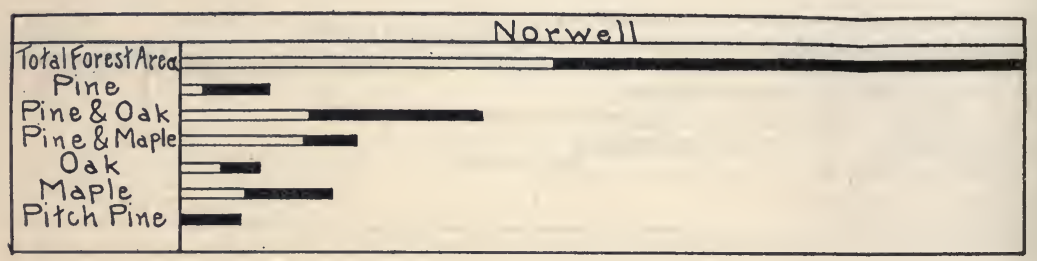


Pembroke.

\begin{tabular}{|c|c|c|c|c|c|c|c|c|c|c|}
\hline & & & \multicolumn{5}{|c|}{ Approximate Size Classes. } & \multirow{2}{*}{ Total. } & \multicolumn{2}{|c|}{ Per Centr. } \\
\hline & & & 1 & 2 & 3 & 4 & 5 & & Forest. & Town. \\
\hline \multicolumn{3}{|c|}{ Forest Types. } & Acres. & Acres. & Acres. & Acres. & Acres. & Acres. & & \\
\hline Pine, . . . & · & . & 408 & 870 & 507 & 22 & 242 & 2,049 & 18.6 & - \\
\hline Pine and oak, . & . & . & 231 & 397 & 705 & 132 & 353 & 1,818 & 16.5 & - \\
\hline Pine and maple, & . & . & - & 220 & 66 & - & 88 & 374 & 3.4 & - \\
\hline Oak type, . . & & . & 55 & 474 & 1,113 & 1,322 & 1,619 & 4,583 & 41.6 & - \\
\hline Maple (swamp) ty & pe, & . & 33 & 297 & 650 & 595 & 77 & 1,652 & 15.0 & - \\
\hline Pitch pine, & & . & - & - & 66 & - & 474 & 540 & 4.9 & - \\
\hline Total, . & . & - & 727 & 2,258 & 3,107 & 2,071 & 2,853 & 11,016 & - & 74.0 \\
\hline Per cent., . & . & . & 6.6 & 20.5 & 28.2 & 18.8 & 25.9 & - & 100.0 & - \\
\hline \multicolumn{8}{|c|}{ Non-Forest Types. } & 2,026 & - & 13.6 \\
\hline Pasture, & . & & . & . & - & • & . & 417 & - & 2.8 \\
\hline Residential, . & · & - & · & · & · & - & - & 74 & - & .5 \\
\hline Water, · & - & • & . & . & . & . & . & 789 & - & 5.3 \\
\hline Cranberry bog, & . & . & . & - & . & - & . & 342 & - & 2.3 \\
\hline Marsh, · · & . $\quad$. & & . & . & . & . & . & 223 & - & 1.5 \\
\hline \multicolumn{3}{|c|}{ Total area of town, } & . & . & - & - & - & 14,887 & - & 100.0 \\
\hline
\end{tabular}

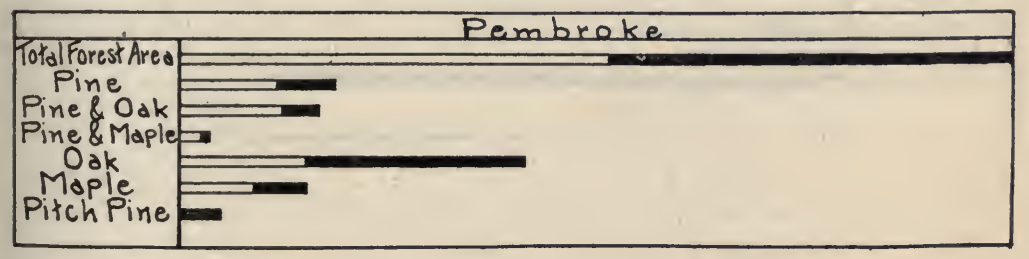




\section{Plymouth.}

\begin{tabular}{|c|c|c|c|c|c|c|c|c|c|c|}
\hline & & & \multicolumn{5}{|c|}{ Approximate Size Classes. } & \multirow{2}{*}{ Total. } & \multicolumn{2}{|c|}{ Per Cent. } \\
\hline & & & 1 & 2 & 3 & 4 & 5 & & Forest. & Town. \\
\hline \multicolumn{3}{|c|}{ Forest TrPes. } & Acres. & Acres. & Acres. & Acres. & Acres. & Acres. & & \\
\hline Pine, . . & & . & 163 & 54 & 218 & 54 & - & 489 & .9 & - \\
\hline Pine and oak, . & & - & 436 & 381 & 1,526 & 981 & 2,070 & 5,394 & 9.9 & - \\
\hline Oak type, . & & - & 272 & 1,362 & 3,269 & 2,397 & 3,978 & 11,278 & 20.7 & - \\
\hline \multicolumn{3}{|c|}{ Pitch pine and scrub oak, } & 708 & 1,417 & 3,433 & 4,413 & 27,353 & 37,324 & 68.5 & - \\
\hline Total, . . & & . $\quad$. & 1,579 & 3,214 & 8,446 & 7,845 & 33,401 & 54,485 & - & 82.5 \\
\hline Per cent., . & & . & 2.9 & 5.9 & 15.5 & 14.4 & 61.3 & - & 100.0 & - \\
\hline \multicolumn{8}{|c|}{ NON-FOREST TYPES. } & 5,020 & - & 7.6 \\
\hline Pasture, & · & . & . & - & . & - & - & 330 & - & .5 \\
\hline Residential, . & . & · & . & - & . & . & . & 1,783 & - & 2,7 \\
\hline Water, . & - & • & . & . & . & . & . & 3,500 & - & 5.3 \\
\hline Cranberry bog, & • & . & . & · & . & · & - & 726 & - & 1.1 \\
\hline Marsh, . . & - & • & . & . & . & . & & 198 & - & .3 \\
\hline \multicolumn{3}{|c|}{ Total area of town, } & - & - & . & - & & 66,042 &.- & 100.0 \\
\hline
\end{tabular}

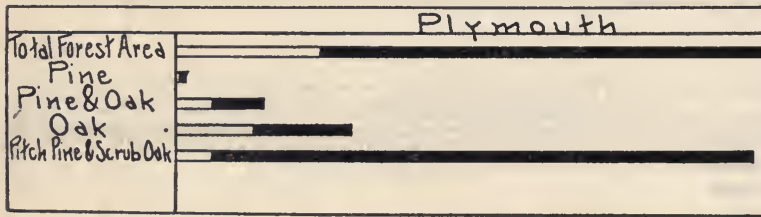


Plympton.

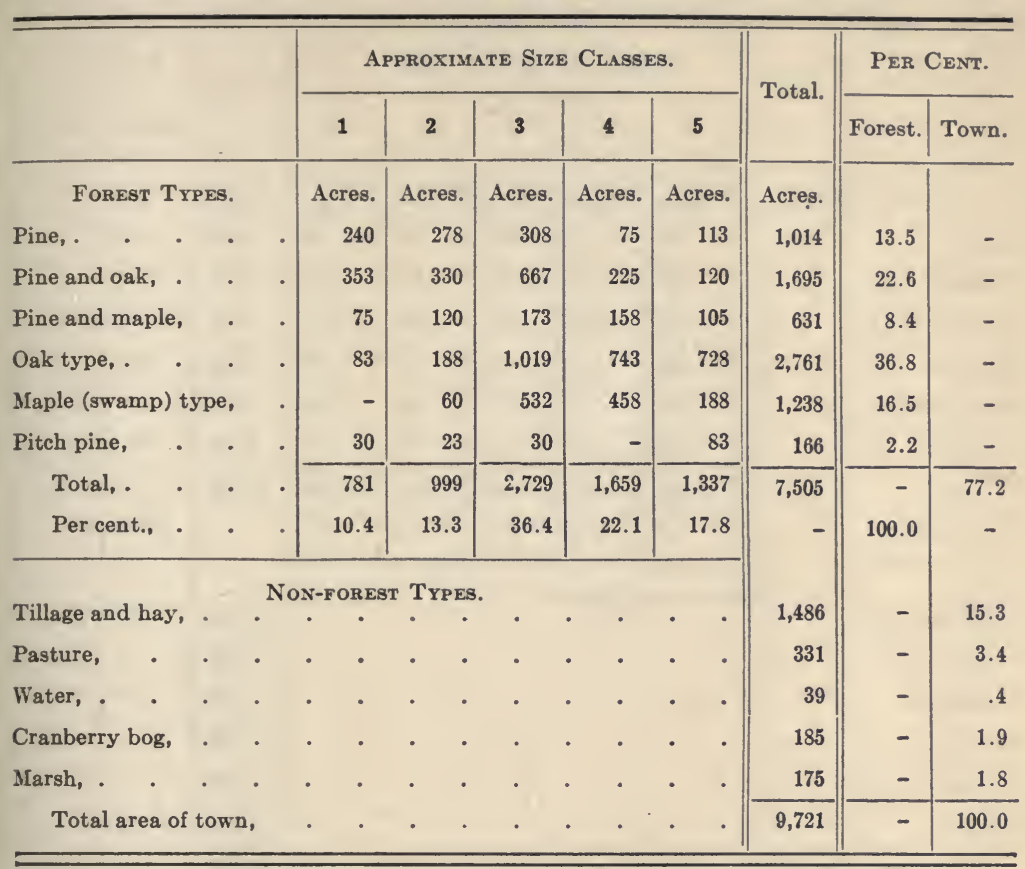

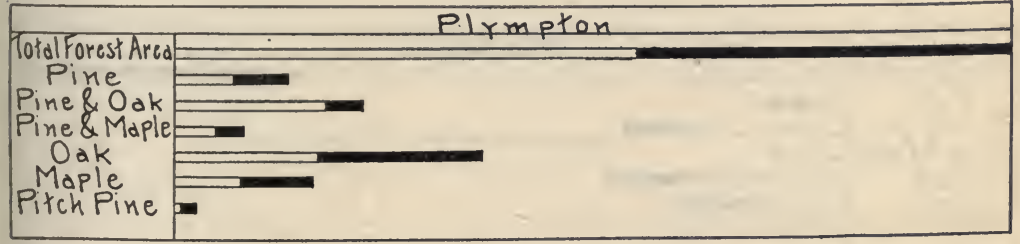


Rochester.

\begin{tabular}{|c|c|c|c|c|c|c|c|c|c|}
\hline & & \multicolumn{5}{|c|}{ Approximate Size Classes. } & \multirow{2}{*}{ Total. } & \multicolumn{2}{|c|}{ Per Centr. } \\
\hline & & 1 & 2 & 3 & 4 & 5 & & Forest. & Town. \\
\hline \multicolumn{2}{|l|}{ Forest TYPES. } & Acres. & Acres. & Acres. & Acres. & Acres. & Acres. & & \\
\hline Pine,. . . . & & 338 & 338 & 596 & 113 & 48 & 1,433 & 8.9 & - \\
\hline Pine and oak, . & & 934 & 918 & 1,255 & 386 & 741 & 4,234 & 26.3 & - \\
\hline Pine and maple, &. & 580 & 370 & 306 & 145 & - & 1,401 & 8.7 & - \\
\hline Oak type,. . & . & 1,240 & 547 & 998 & 612 & 1,208 & 4,605 & 28.6 & - \\
\hline Maple (swamp) type, & . & 193 & 757 & 773 & 885 & 628 & 3,236 & 20.1 & - \\
\hline Pitch pine, & . & 419 & 467 & 64 & 177 & 64 & 1,191 & 7.4 & - \\
\hline Total, . & . & 3,704 & 3,397 & 3,992 & 2,318 & 2,689 & 16,100 & - & 69.8 \\
\hline Per cent., . & . & 23 & 21.1 & 24.8 & 14.4 & 16.7 & - & 100.0 & - \\
\hline \multicolumn{7}{|c|}{ NON-FOREST TYPES. } & 3,206 & - & 13.9 \\
\hline Pasture, . . & . & . & . & . & . & . & 1,107 & - & 4.8 \\
\hline Residential, . & . & . & . & . & . & . & 323 & - & 1.4 \\
\hline Water, . & . & . & . & . & . & . & 1,338 & - & 5.8 \\
\hline Cranberry bog, & . & . & . & . & . & . & 784 & - & 3.4 \\
\hline Marsh, . . . . & . & - & . & . & . & . & 208 & - & .9 \\
\hline \multicolumn{2}{|l|}{ Total area of town, } & . & . & . & . & . & 23,066 & - & 100.0 \\
\hline
\end{tabular}

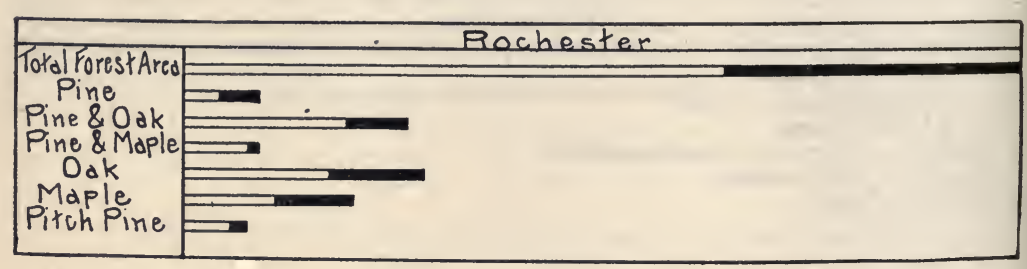


RockLAND.

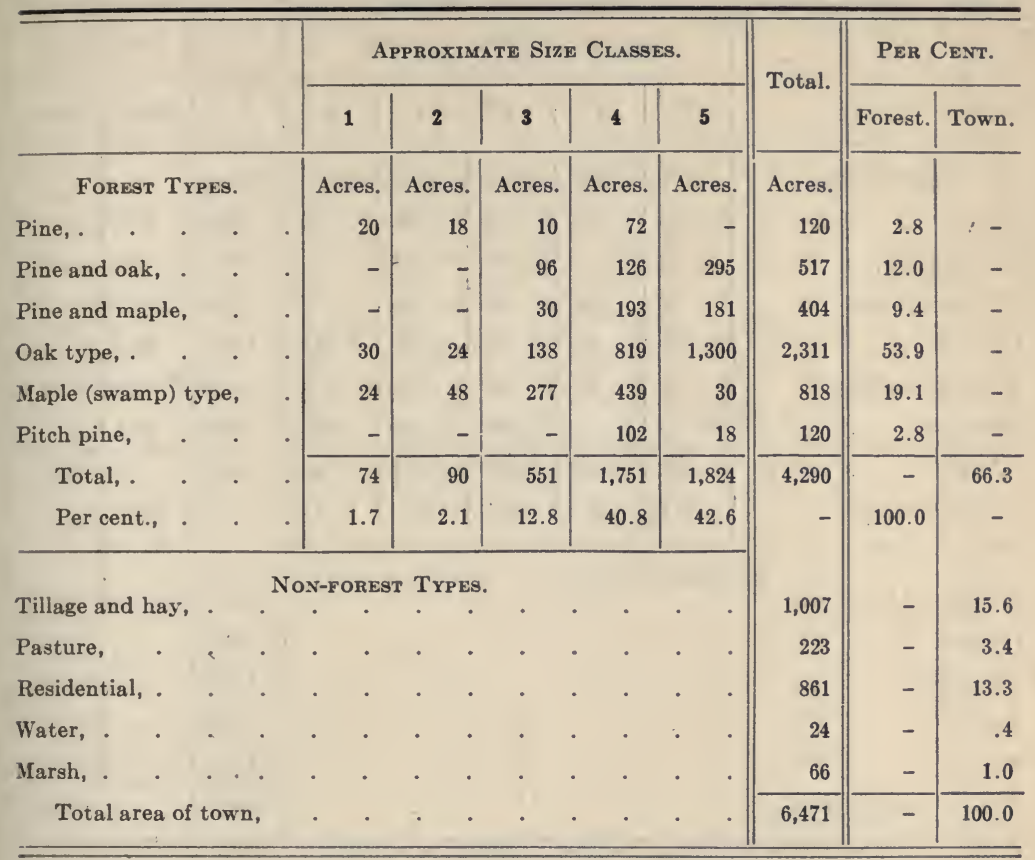

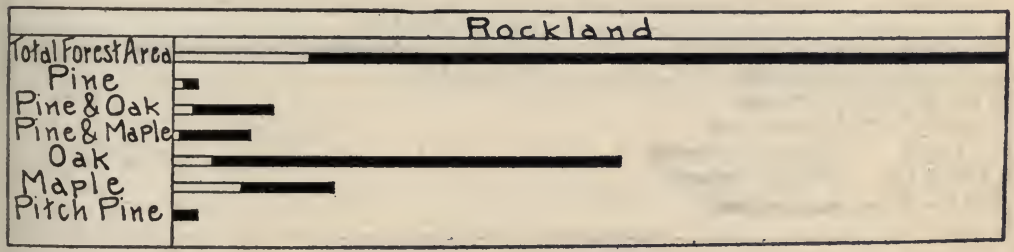


Scituate.

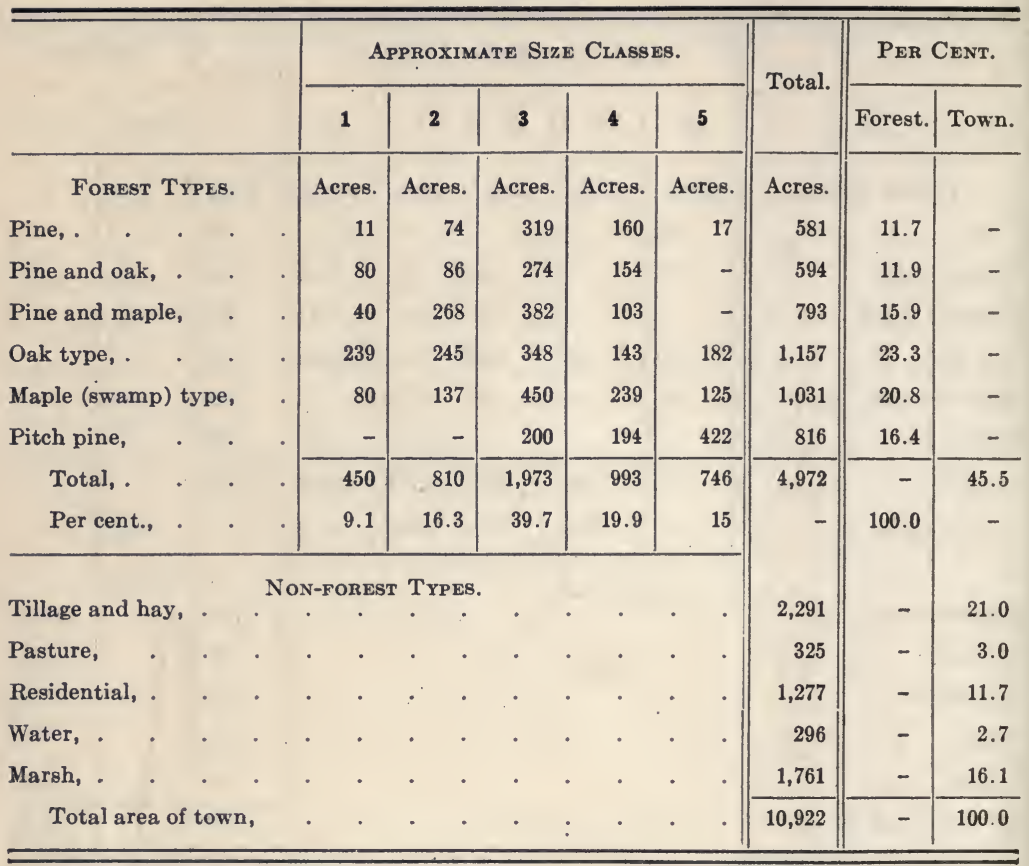

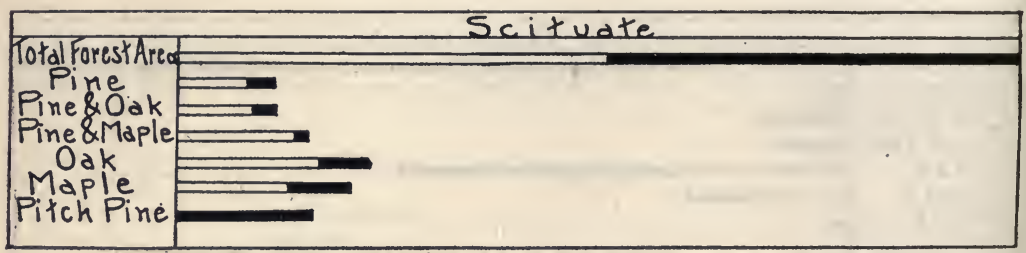


WAREHAM.

\begin{tabular}{|c|c|c|c|c|c|c|c|c|c|c|}
\hline & & & \multicolumn{5}{|c|}{ Approximate Size Classes. } & \multirow{2}{*}{ Total. } & \multicolumn{2}{|c|}{ Per Cent. } \\
\hline 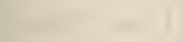 & & & 1 & 2 & 3 & 4 & 5 & & Forest. & Town. \\
\hline \multicolumn{3}{|c|}{ Forest TyPES. } & Acres. & Acres. & Acres. & Acres. & Acres. & Acres. & & \\
\hline Pine, . & . & . & 49 & 196 & 49 & - & 82 & 376 & 2.3 & - \\
\hline Pine and oak, . & . & . & 443 & 376 & 950 & 327 & 917 & 3,013 & 18.4 & - \\
\hline Pine and maple, & . & . & 82 & 16 & 49 & - & 49 & 196 & 1.2 & - \\
\hline Oak type, . & . & . & 312 & 655 & 917 & 327 & 605 & 2,816 & 17.2 & - \\
\hline Maple (swamp) $t$ & ype, & . & 16 & 49 & 65 & 147 & 82 & 359 & 2.2 & - \\
\hline Pitch pine, & . & . & 278 & 950 & 1,981 & 1,425 & 4,961 & 9,595 & 58.7 & - \\
\hline Total, . & . & . & 1,180 & 2,242 & 4,011 & 2,226 & 6,696 & 16,355 & - & 67.2 \\
\hline Per cent., . & . & . & 7.2 & 13.7 & 24.5 & 13.6 & 41 & - & 100.0 & - \\
\hline \multicolumn{8}{|c|}{ NON-FOREST TYPES. } & 2,750 & - & 11.3 \\
\hline Pasture, . & . & . & . & . & . & . & . & 535 & - & 2.2 \\
\hline Residential, . & . & . & . & . & . & . & . & 535 & - & 2.2 \\
\hline Water, . & . & . & . & . & . & . & . & 1,947 & - & 8.0 \\
\hline Cranberry bog, & . & . & . & . & . & - & . & 1,047 & - & 4.3 \\
\hline Marsh, . . & - & . & . & . & . & . & . & 1,169 & - & 4.8 \\
\hline \multicolumn{3}{|c|}{ Total area of town, } & . & . & . & . & . & 24,338 & - & 100.0 \\
\hline
\end{tabular}

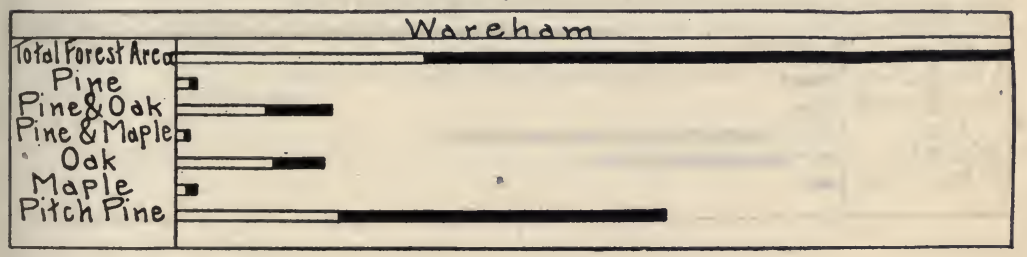


West Bridgewater.

\begin{tabular}{|c|c|c|c|c|c|c|c|c|c|c|}
\hline & & & \multicolumn{5}{|c|}{ Approximate Size Crasses. } & \multirow{2}{*}{ Total. } & \multicolumn{2}{|c|}{ Per Cent. } \\
\hline & & & 1 & 2 & 3 & 4 & 5 & & Forest. & Town. \\
\hline \multicolumn{3}{|c|}{ FOREST TYPES. } & Acres. & Acres. & Acres. & Acres. & Acres. & Acres. & & \\
\hline Pine, . . . & & & 58 & 105 & 41 & 17 & 23 & 244 & 4.4 & - \\
\hline Pine and oak, . & & & 12 & - & 76 & 174 & 145 & 407 & 7.3 & - \\
\hline Pine and maple, & . & . & - & 29 & 105 & 168 & 23 & 325 & 5.8 & - \\
\hline Oak type,. . & & . & 110 & 116 & 401 & 657 & 1,418 & 2,702 & 48.2 & - \\
\hline Maple (swamp) $t$ & ype, & . & - & 52 & 407 & 999 & 250 & 1,708 & 30.5 & - \\
\hline Pitch pine, & & . & - & - & - & - & 216 & 216 & 3.8 & - \\
\hline Total, . & . & . & 180 & 302 & 1,030 & 2,015 & 2,075 & 5,602 & - & 55.6 \\
\hline Per cent., & . & . & 3.2 & 5.4 & 18.4 & 36 & 37 & - & 100.0 & - \\
\hline \multicolumn{8}{|c|}{ NON-FOREST TYPES. } & 3,081 & - & 30.6 \\
\hline Pasture, & . & . & . & . & . & . & . & 767 & - & 7.6 \\
\hline Residential, . & . & . & . & . & . & . & . & 535 & - & 5.3 \\
\hline Water, . & . & . & . & . & . & . & . & 52 & - & .5 \\
\hline Marsh, . & . & . & - & . & . & . & . & 46 & - & .4 \\
\hline \multicolumn{3}{|c|}{ Total area of town, } & . & . & . & . & . & 10,083 & - & 100.0 \\
\hline
\end{tabular}

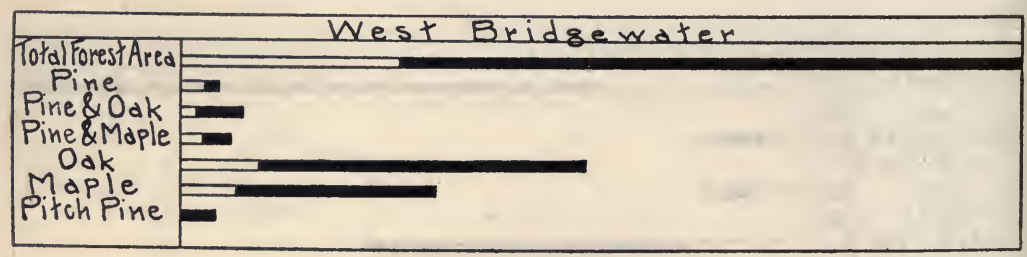


WhitMaN.

\begin{tabular}{|c|c|c|c|c|c|c|c|c|c|}
\hline & & \multicolumn{5}{|c|}{ Approximate Size Classes. } & \multirow{2}{*}{ Total. } & \multicolumn{2}{|c|}{ Per Cent. } \\
\hline & & 1 & 2 & 3 & 4 & 5 & & Forest. & Town. \\
\hline Forest Types. & & Acres. & Acres. & Acres. & Acres. & Acres. & Acres. & & \\
\hline Pine,. $\quad . \quad . \quad$. & . & - & - & 122 & - & - & 122 & 6.4 & - \\
\hline Pine and oak, . & . & - & - & 30 & 61 & 55 & 146 & 7.6 & - \\
\hline Oak type, 1 & - & - & 24 & 225 & 565 & 502 & 1,316 & 68.6 & - \\
\hline Maple (swamp type), & . & - & - & - & 213 & 85 & 298 & 15.5 & - \\
\hline Pitch pine, $\quad$. & . & - & - & - & 37 & - & 37 & 1.9 & - \\
\hline Total, . & . & - & 24 & 377 & 876 & 642 & 1,919 & - & 42.9 \\
\hline Per cent., . & . & - & 1.3 & 19.6 & 45.6 & 33.5 & - & 100.0 & - \\
\hline Tillage and hay, . &.$^{N C}$ & N-FOREST & T TYPEs. & . & - & . & 952 & - & 21.3 \\
\hline Pasture, . . & . & . & .. & . & . & . & 475 & - & 10.6 \\
\hline Residential, . . & . & . & . & . & . & . & 1,070 & - & 23.8 \\
\hline Marsh, . . . . & . & $\cdot$ & - & . & . & . & $\mathbf{5 7}$ & - & 1.3 \\
\hline Total area of town & & . & . & - & . & . & 4,473 & - & 100.0 \\
\hline
\end{tabular}

1 Considerable maple in mixture in medium and small sizes.

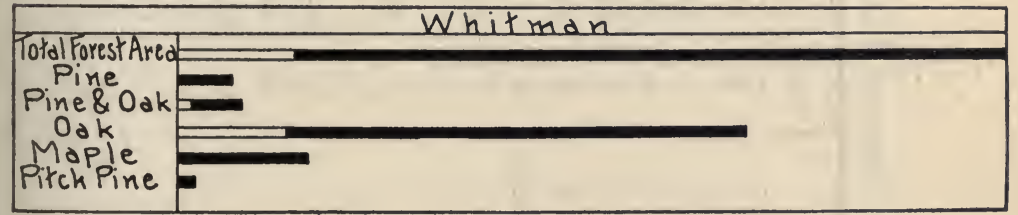




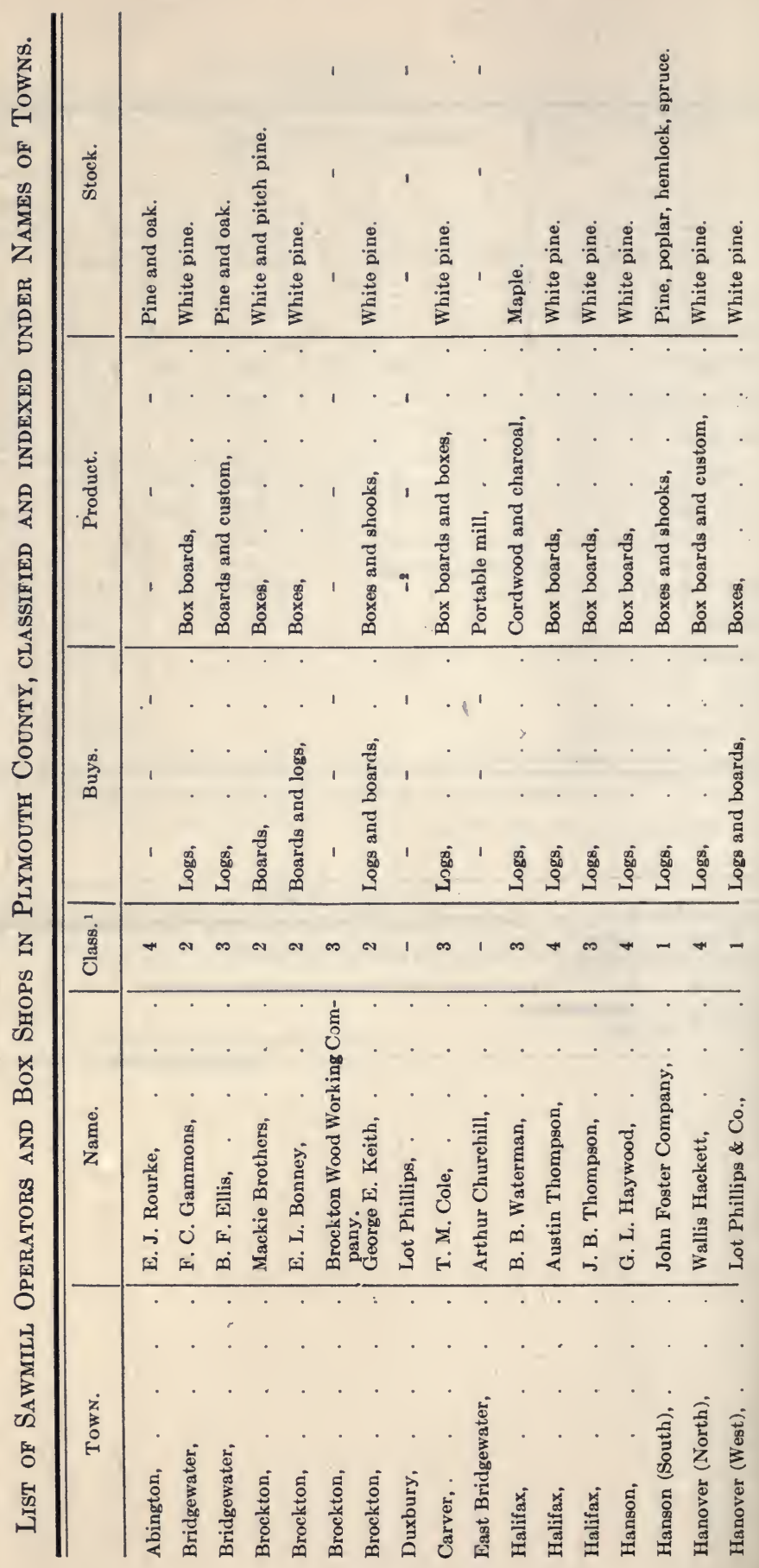




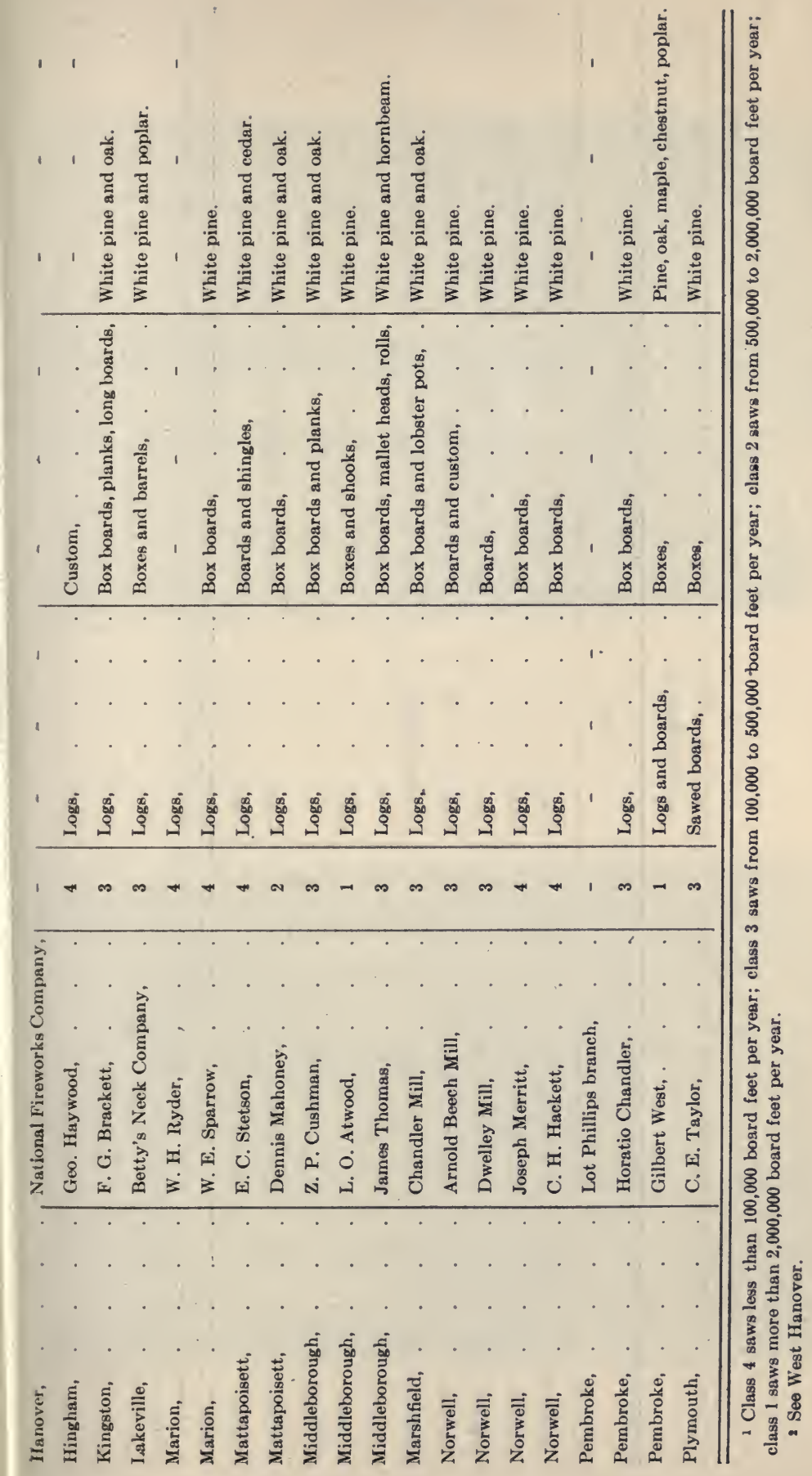




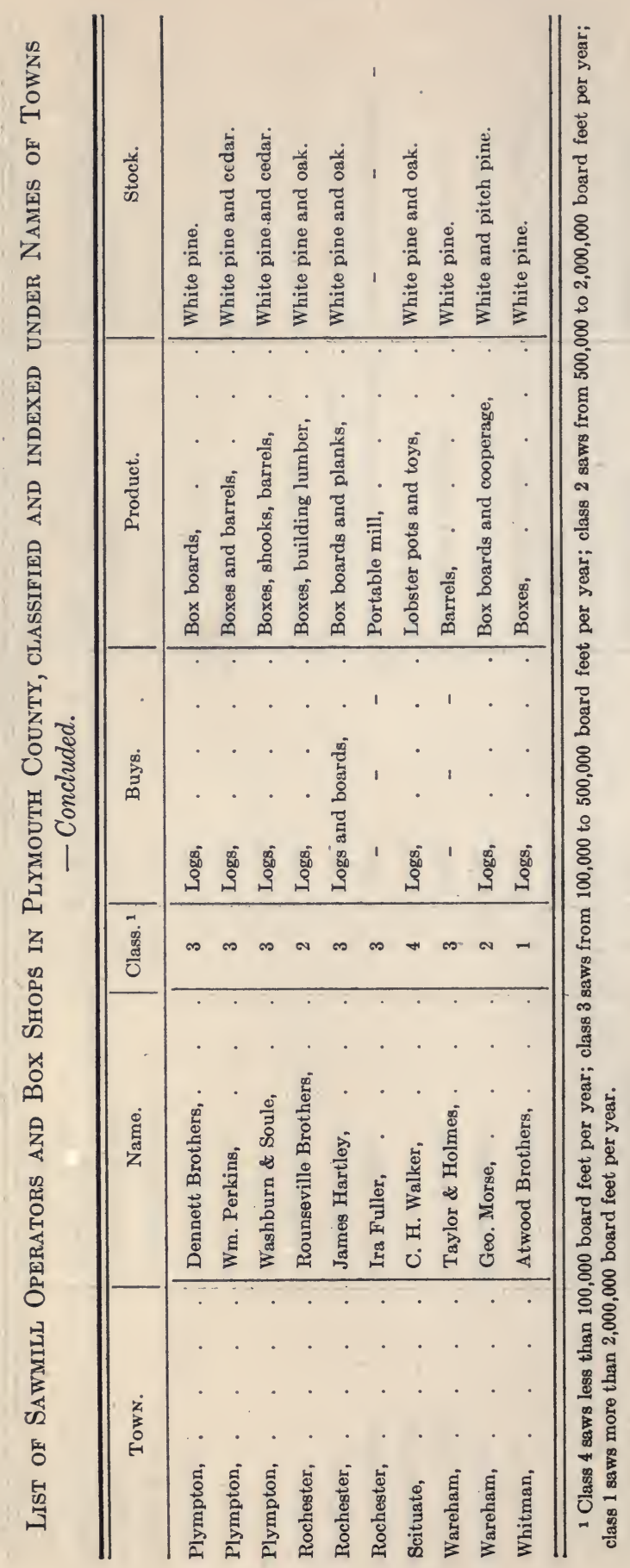



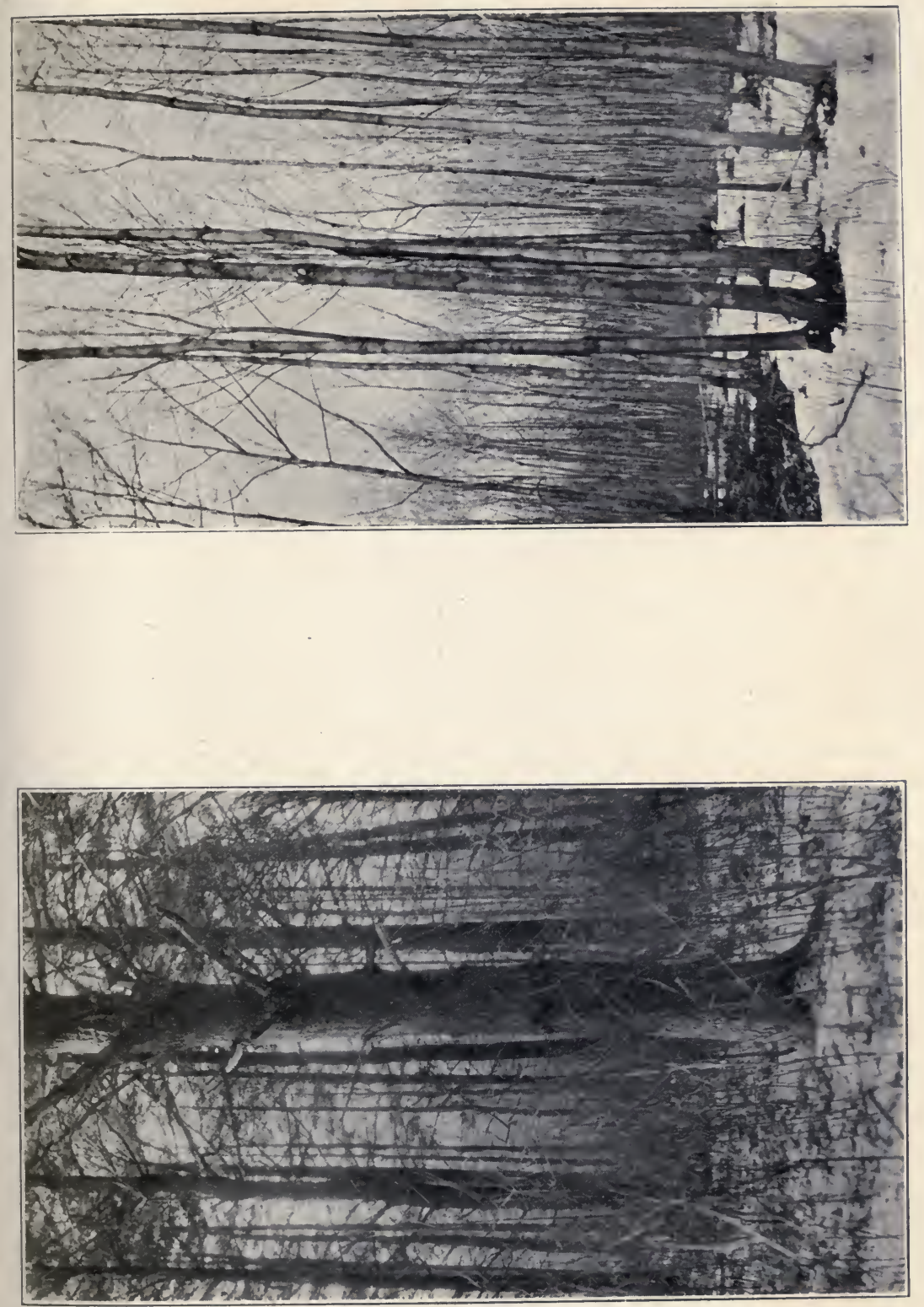



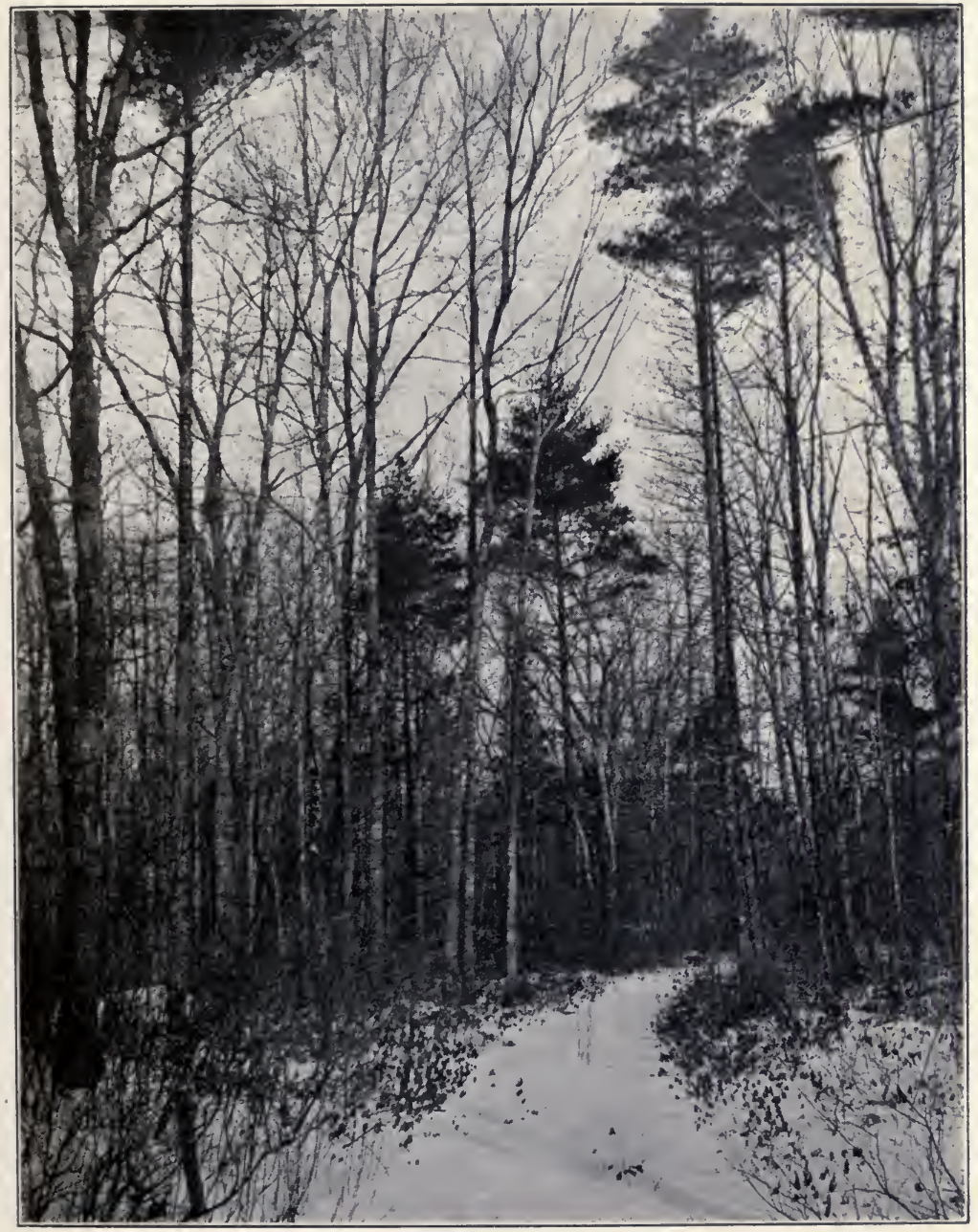

Pine, maple and oak. Diameters, 6 to 10 inches; heights, 50 to 60 feet. (Pine and hardwoods type, Class 2.) 



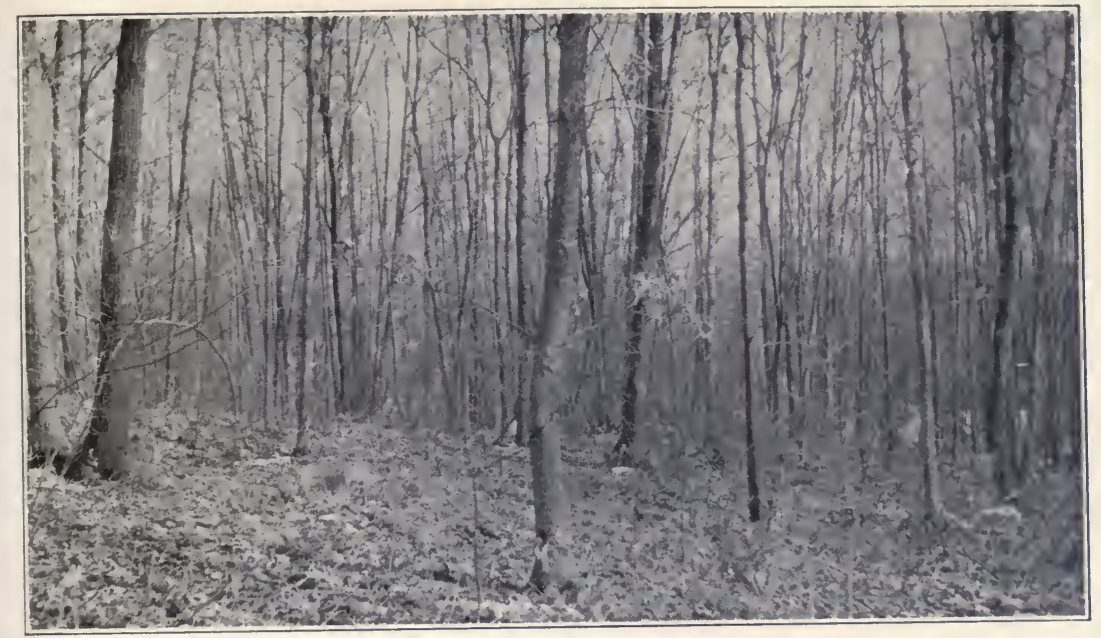

Oak type. Diameter, about 5 inches; heights, 40 to 50 feet. (Class 3 .)

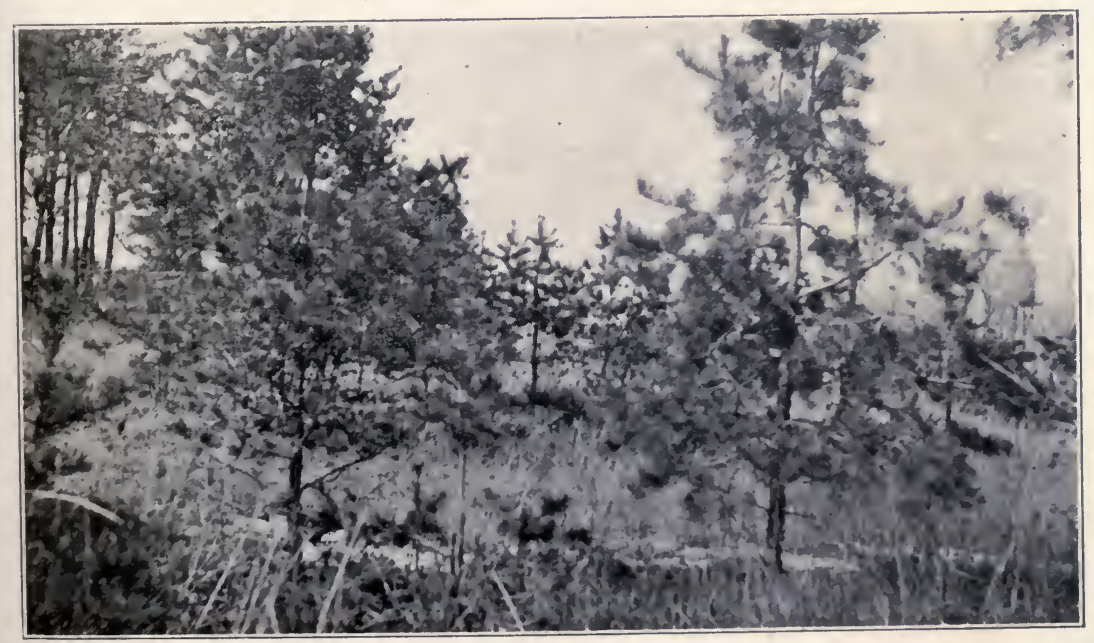

Pitch pine type. (Classes 4 and 5.) 



Pamphlets

$213 \mathrm{P3}$

Massqchusets र. 9

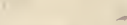


